\title{
Thermodynamic modeling of La2O3-SrO-Mn2O3-Cr2O3 for solid oxide fuel cell applications
}

\section{Journal Article}

\section{Author(s):}

Povoden-Karadeniz, E.; Chen, M.; Ivas, T.; Grundy, A. N.; Gauckler, L. J.

Publication date:

2012-08

Permanent link:

https://doi.org/10.3929/ethz-b-000055345

Rights / license:

In Copyright - Non-Commercial Use Permitted

\section{Originally published in:}

Journal of Materials Research 27(15), https://doi.org/10.1557/jmr.2012.149 


\title{
Thermodynamic modeling of $\mathrm{La}_{2} \mathrm{O}_{3}-\mathrm{SrO}-\mathrm{Mn}_{2} \mathrm{O}_{3}-\mathrm{Cr}_{2} \mathrm{O}_{3}$ for solid oxide fuel cell applications
}

\author{
E. Povoden-Karadeniz ${ }^{\text {a) }}$ \\ Nonmetallic Inorganic Materials, Department of Materials, Eidgenössische Technische Hochschule (ETH) Zürich, \\ 8093 Zurich, Switzerland \\ M. Chen \\ DTU Energy Conversion, Department of Energy Conversion and Storage, Technical University of Denmark, \\ 4000 Roskilde, Denmark \\ Toni Ivas ${ }^{\text {b) }}$ \\ Nonmetallic Inorganic Materials, Department of Materials, Eidgenössische Technische Hochschule (ETH) Zürich, \\ 8093 Zurich, Switzerland \\ A.N. Grundy \\ Concast AG, 8002 Zurich, Switzerland \\ L.J. Gauckler \\ Nonmetallic Inorganic Materials, Department of Materials, Eidgenössische Technische Hochschule (ETH) Zürich, \\ 8093 Zurich, Switzerland
}

(Received 6 December 2011; accepted 23 April 2012)

The thermodynamic $\mathrm{La}-\mathrm{Sr}-\mathrm{Mn}-\mathrm{Cr}-\mathrm{O}$ oxide database is obtained as an extension of thermodynamic descriptions of oxide subsystems using the calculation of phase diagrams approach. Concepts of the thermodynamic modeling of solid oxide phases are discussed. Gibbs energy functions of $\mathrm{SrCrO}_{4}, \mathrm{Sr}_{2.67} \mathrm{Cr}_{2} \mathrm{O}_{8}, \mathrm{Sr}_{2} \mathrm{CrO}_{4}$, and $\mathrm{SrCr}_{2} \mathrm{O}_{4}$ are presented, and thermodynamic model parameters of $\mathrm{La}-\mathrm{Sr}-\mathrm{Mn}-\mathrm{Chromite}$ perovskite are given. Experimental solid solubilities and nonstoichiometries in $\mathrm{La}_{1-x} \mathrm{Sr}_{x} \mathrm{CrO}_{3-\delta}$ and $\mathrm{LaMn}_{1-x} \mathrm{Cr}_{x} \mathrm{O}_{3-\delta}$ are reproduced by the model. The presented oxide database can be used for applied computational thermodynamics of traditional lanthanum manganite cathode with $\mathrm{Cr}$-impurities. It represents the fundament for extensions to higher orders, aiming on thermodynamic calculations in noble symmetric solid oxide fuel cells.

\section{INTRODUCTION}

\section{A. The role of computational thermodynamics for solid oxide fuel cells research}

In a recent review, symmetric solid oxide fuel cells (SOFC), where the same electrode material is used as anode and cathode, have been a promising concept $^{1}$ : while being as efficient as conventional SOFC, symmetric SOFC have advantages regarding both fabrication and operation. A working model system for this configuration with redoxstable electrodes made of $\mathrm{La}-\mathrm{Sr}-\mathrm{Mn}-\mathrm{Chromite}$ (LSCM) with the perovskite structure $\mathrm{ABO}_{3-\delta}$ was presented by Refs. 2 and 3.

In traditional SOFC, Sr-doped lanthanum manganite (LSM) with the perovskite structure is used as cathode

\footnotetext{
a) Address all correspondence to this author.

e-mail: erwin.povoden-karadeniz@ tuwien.ac.at

Present address: Christian Doppler Laboratory for Early Stages of Precipitation, Institute of Materials Science and Technology, Vienna University of Technology, Favoritenstraße 9-11, Vienna, A-1040, Austria

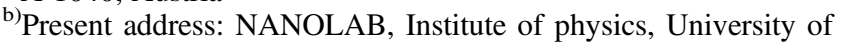
Basel, 4056 Basel, Switzerland

DOI: $10.1557 /$ jmr.2012.149
}

materials in SOFC. However, uncontrolled diffusion of chromium from the metallic interconnects into the cathode leads to a severe cell voltage decrease that was linked to the formation of Cr-containing phases., Thermodynamic calculations are feasible for a deeper understanding of the mechanisms of chromium "poisoning" since the effects of increasing chromium content inside the cathode on the formation of phases such as $\mathrm{Cr}-\mathrm{Mn}$ spinel, being harmful for the cell performance, can be calculated. Also, conclusions on the evolution of the phase chemistry of degraded LSM cathodes can be drawn. One can calculate the expected equilibrium state under reducing oxygen partial pressures, the latter reflecting the situation at the cathode-electrolyte interface in SOFC under current load. By modeling oxygen nonstoichiometry of LSCM, trends of the ionic conductivity of the cathode can be evaluated. The evolution of phase relations in SOFC at varying oxygen partial pressures represents a multicomponent problem. Computational thermodynamics in SOFC research utilizing oxide database assists understanding of phase relations at different positions inside SOFC at long-term operation, i.e. the closer the material approaches thermodynamic equilibrium. Of particular interest is a deeper knowledge of the 
thermodynamics at the complex interfaces inside SOFC, the interconnect/electrode, as well as electrochemically active electrode/electrolyte interfaces. A thermodynamic $\mathrm{La}-\mathrm{Sr}-\mathrm{Mn}-\mathrm{Cr}-\mathrm{O}$ oxide database is highly desirable, to understand phase formations due to solid-gas and solidsolid reaction, affecting cell performance. A thermodynamic database contains the optimized Gibbs energy functions of solid oxide phases, for stoichiometric phases (line compounds) as a function of temperature and for solid solution phases as a function of temperature and composition. From the above example of thermodynamic computations of Cr-contaminated LSM, it is obvious that the database should meet the demand to calculate stable and metastable phase equilibria, thermodynamic driving forces and activities, as well as defect concentrations of LSCM at different temperatures and oxygen partial pressures. These requirements are conformed by using the calculation of phase diagrams (CALPHAD) approach $^{6-8}$ : model parameters for the molar Gibbs energies of the phases of a system are evaluated from experimental thermochemical and equilibrium phase diagram data, the latter representing areas of minimal Gibbs energy in function of temperature, pressure (in this study, constant atmospheric pressure), and composition. Experimental thermochemical data include for instance calorimetric results (enthalpies of formation, heat capacities). With gas phase equilibria techniques such as Knudsen mass spectrometry, the vapor pressure of component of interest is measured to derive its activity. Electromotive force (emf) generated by electrochemical cells is used to derive the standard Gibbs energy of formation of a phase. More details of these and less common techniques can be found in Ref. 6. The power of the CALPHAD approach is that the thermodynamic properties of a multicomponent phase, such as LSCM, i.e., its molar enthalpy, entropy, heat capacity, and Gibbs energy, are founded on the thermodynamics of its forming simple oxides, and only the excess contribution to its molar Gibbs energy, in essence the nonideal Gibbs energy of mixing, is optimized with experimental thermodynamic and phase diagram data. In principle, optimizations are made in low-order binary and pseudobinary systems, where experimental information is available (in the following, a three-component oxide system with binary oxide end-members is named pseudobinary, a four-component oxide system with three binary end-members is named pseudoternary, and so forth). On this fundament, reasonable assumptions can be made about the thermodynamics of high-order systems, where experimental data are scarce or missing. To allow extension from low-order systems to multicomponent databases, a common reference for the molar enthalpy is defined, which for an element is the standard molar enthalpy of its stable modification at $298.15 \mathrm{~K}$ (SER $=$ Stable Element Reference). Also, it is required that the same Gibbs energy functions of pure elements, compiled by Dinsdale, ${ }^{9}$ are used in all thermodynamic assessments. The molar entropy of a phase is zero at $0 \mathrm{~K}$ and must of course obtain positive values at finite temperatures.

\section{B. CALPHAD modeling of solid oxides}

\section{Stoichiometric solid oxides}

A ternary line compound $\alpha$, containing $m$ and $n$ moles of two different sorts of cations, $a$ with the positive electrical charge $r$ and $b$ with the positive electrical charge $q$, respectively, and $p$ moles of one sort of anions, $c$ with the negative electrical charge $s$, the three types of ions sitting in three distinctive crystallographic sublattices (i.e., nonequivalent Wyckoff sites $\left.{ }^{8}\right)$, can be described by the sublattice formula $\left(a^{r}\right)_{m}\left(b^{q}\right)_{n}\left(c^{s}\right)_{p}$. For oxides, $c=\mathrm{O}$ and charge $s=-2$. To account for the charge neutrality criterion, Eq. (1) is true.

$$
p q=m r-2 n .
$$

The molar Gibbs energy of $\alpha,{ }^{\circ} G_{\mathrm{m}}^{\alpha}$ at constant pressure is given by

$$
{ }^{\circ} G_{\mathrm{m}}^{\alpha}=A+B T+C T \ln T+D T^{2}+E T^{3}+F T^{(-1)}
$$

where $A, B, C, D, E$, and $\mathrm{F}$ are model parameters to be optimized by thermodynamic and phase diagram data. Since the heat capacity at constant pressure, $\operatorname{Cp}(\alpha)$ is defined by:

$$
C_{\mathrm{p}}=-C-2 D T-6 E T^{2}-2 F T^{-2},
$$

$C, D, E$, and $F$ are optimized to heat capacity data only. ${ }^{\circ} G_{\mathrm{m}}^{\alpha}$ can be based on the molar Gibbs energies of $\alpha$-forming oxides $\left(a^{r}\right)_{t}\left(\mathrm{O}^{2-}\right)_{u}$ and $\left(b^{q}\right)_{v}\left(\mathrm{O}^{2-}\right)_{\mathrm{w}}$ $(t, u, v, w \in \mathrm{N})$, if it is assumed that the heat capacity of the ternary oxide composed by the two binary oxides is simply the sum of the heat capacities of the composing oxides [based on Neumann (1831) and Kopp's (1964) rule that the molar heat capacity of a solid compound is the sum of the heat capacities of the elements in it] as shown in Eq. (4):

$$
\begin{aligned}
& { }^{\circ} G_{\mathrm{m}}^{\alpha}={ }^{\circ} G_{\mathrm{m}}^{\left(a^{r}\right)_{m}\left(b^{q}\right)_{n}\left(\mathrm{O}^{2-}\right)_{p}} \\
& =\frac{m}{t} G_{\mathrm{m}}^{\left(a^{r}\right)_{t}\left(\mathrm{O}^{2-}\right)_{u}}+\frac{n}{v}{ }^{\circ} G_{\mathrm{m}}^{\left(b^{q}\right)_{v}\left(\mathrm{O}^{2-}\right)_{w}} \\
& +\frac{p t v-m u v-n w t}{2 t v} G_{\mathrm{m}}^{\mathrm{O}_{2}(g)}+A+B T,
\end{aligned}
$$

where ${ }^{\circ} G_{\mathrm{m}}^{\alpha}$ is the Gibbs energy of formation of the phase $\alpha$ relative to the oxide components. $A$ and $B$ are optimized by thermodynamic and phase diagram data. 


\section{Solid solution phases-the Compound Energy Formalism}

LSCM perovskite is the important solid solution phase for SOFC to be modeled in the multicomponent database presented. To understand its thermodynamic modeling, let us consider the simple case of an oxide phase $\beta$ with sublattices $\left(a^{r}\right)_{t}\left(\mathrm{O}^{2-}\right)_{u}$ containing cation $a$ with the positive charge $r$. When another sort of cation with the positive charge $q, b^{q}$ sits in the same sublattice as $a$; the sublattice formula of the resulting solid solution phase $\beta$ (ss) reads $\left(a^{r}, b^{q}\right)_{t}\left(\mathrm{O}^{2-}\right)_{u}$. Equation (5) is the criterion for charge neutrality:

$$
-2 u=t(r+q) \quad .
$$

Using the Compound Energy Formalism (CEF) ${ }^{10-12}$ the molar Gibbs energy of the solid solution (ss) phase comprises the Gibbs energies of the compounds. For $\beta(\mathrm{ss})$, the two compounds read $\left(a^{r}\right)_{t}\left(\mathrm{O}^{2-}\right)_{u}$ and $\left(b^{q}\right)_{t}\left(\mathrm{O}^{2-}\right)_{u}$. The Gibbs energy of $\beta(\mathrm{ss})$ at constant pressure reads

$$
\begin{aligned}
{ }^{\circ} G_{\mathrm{m}}^{\beta \mathrm{ss}}= & y_{a^{r}}{ }^{\circ} G^{\left(a^{r}\right)_{t}\left(\mathrm{O}^{2-}\right)_{u}}+y_{b^{q}}{ }^{\circ} G^{\left(b^{q}\right)_{t}\left(\mathrm{O}^{2-}\right)_{u}} \\
& +t R T\left(y_{a^{r}} \ln y_{a^{r}}+y_{b^{q}} \ln y_{a^{r}}\right)+{ }^{\mathrm{E}} G_{\mathrm{m}}^{\beta \mathrm{ss}},
\end{aligned}
$$

where $y_{a^{r}}$ is the fraction of cation $a$ on the cation sublattice (site fraction), and $y_{b^{q}}$ is the site fraction of cation $b$ on the cation sublattice. $R=8.31451 \mathrm{~J} /(\mathrm{mol} \mathrm{K})$. The second last term accounts for the configurational entropy of mixing, related to the number of possible configurations of $a$ and $b$. The last term describes the excess Gibbs energy of mixing due to interactions of ions in the mixture that can be accounted for by introducing interaction parameters, in the following denoted with ${ }^{0} L$ to ${ }^{n} L$, where only the 0 th interaction parameter denotes composition-independent interaction energies. The form of interaction energies as Redlich-Kister ${ }^{13}$ polynomials has been described in detail elsewhere, e.g., Liu. $^{8}$

\section{Vacancies and the concept of reciprocal reactions}

Let an oxide phase $(\mathrm{A})_{2}(\mathrm{~B})_{3}$, where A stands for the cation sublattice and $\mathrm{B}$ denotes the anion sublattice, contain one cation $a$ accepting the charge $3+$ or $2+$ in the cation sublattice. When the cation is reduced, the charge neutrality criterion is no longer obeyed by an anionic sublattice that is completely filled with oxygen. Charge neutrality under such reducing conditions can be conserved by the formation of zero-charged vacancies (Va) in the anionic sublattice resulting in the phase becoming oxygen-nonstoichiometric. In the sublattice form, the phase can be written as $\left(a^{3+}, a^{2+}\right)_{2}\left(\mathrm{O}^{2-}, \mathrm{Va}\right)_{3}$. The oxygen nonstoichiometry is denoted " $\mathrm{O}_{3-\delta}$." The molar Gibbs energy of the phase at constant pressure reads

$$
\begin{aligned}
{ }^{\circ} G_{\mathrm{m}}^{A_{2} \mathrm{O}_{3-\delta}=}= & { }^{\circ} G_{\mathrm{m}}^{\left(a^{3+}, a^{2+}\right)_{2}\left(\mathrm{O}^{2-}, \mathrm{Va}\right)_{3}} \\
= & y_{a^{3+}} G_{\mathrm{m}}^{\left(a^{3+}\right)_{2}\left(\mathrm{O}^{2-}\right)_{3}}+y_{a^{2+}}{ }^{\circ} G_{\mathrm{m}}^{\left(a^{2+}\right)_{2}\left(\mathrm{O}^{2-}\right)_{3}} \\
& +y_{a^{3+}}{ }^{\circ} G_{\mathrm{m}}^{\left(a^{3+}\right)_{2}(\mathrm{Va})_{3}}+y_{a^{2+}} G_{\mathrm{m}}^{\left(a^{2+}\right)_{2}(\mathrm{Va})_{3}} \\
& +2 R T\left(y_{a^{3+}} \ln y_{a^{3+}}+y_{a^{3+}} \ln y_{a^{2+}}\right) \\
& +3 R T\left(y_{\mathrm{O}^{2-}} \ln y_{\mathrm{O}^{2-}}+y_{\mathrm{Va}} \ln y_{\mathrm{Va}}\right) \\
& +{ }^{\mathrm{E}} G_{\mathrm{m}}^{\left(a^{3+}, a^{2+}\right)_{2}\left(\mathrm{O}^{2-}, \mathrm{Va}\right)_{3}} .
\end{aligned}
$$

Four end-member compounds of the phase are obtained by simple recombinations of $2+$ or $3+$ cations with oxygen anions or vacancies. The molar Gibbs energies of all the four end-member compounds $\left(a^{3+}\right)_{2}\left(\mathrm{O}^{2-}\right)_{3}$, $\left(a^{2+}\right)_{2}\left(\mathrm{O}^{2-}\right)_{3},\left(a^{3+}\right)_{2}(\mathrm{Va})_{3}$, and $\left(a^{2+}\right)_{2}(\mathrm{Va})_{3}$ are required for the molar Gibbs energy of the phase. However, the only neutral end-member is $\left(a^{3+}\right)_{2}\left(\mathrm{O}^{2-}\right)_{3}$. It thus can exist, and its molar Gibbs energy can be defined by optimization of model parameters by experiments. The three other endmembers are charged and cannot exist, but a line of neutral compositions connects $\left(a^{3+}\right)_{2}\left(\mathrm{O}^{2-}\right)_{3}$ with the reduced compound $\left(a^{2+}\right)_{2}\left(2 / 3 \mathrm{O}^{2-} \mathrm{Va}\right)_{3}$, and its Gibbs energy can be optimized with experiments that are related to the reduction of the phase, for instance oxygen nonstoichiometry data.

The composition square of the phase can be seen in Fig. 1 that is redrawn from Hillert, ${ }^{12}$ with the neutral line and the reduced compound, denoted with $\mathrm{R}$, included. The $2+$ charged center composition of the square, $\left(a^{3+} a^{2+}\right)_{2}\left(3 / 2 \mathrm{O}^{2-} 3 / 2 \mathrm{Va}\right)_{3}$, denoted with $\mathrm{A}$ in Fig. 1 , is theoretically obtained by mixing equal amounts of either $\left(a^{3+}\right)_{2}\left(\mathrm{O}^{2-}\right)_{3}$ and $\left(a^{2+}\right)_{2}(\mathrm{Va})_{3}$ or $\left(a^{3+}\right)_{2}(\mathrm{Va})_{3}$ and $\left(a^{2+}\right)_{2}\left(\mathrm{O}^{2-}\right)_{3}$.

A system that obeys this relation is called a reciprocal system, and $\left(a^{3+}, a^{2+}\right)_{2}\left(\mathrm{O}^{2-}, \mathrm{Va}\right)_{3}$ is a reciprocal phase. ${ }^{12}$ For an unambiguous definition of the molar Gibbs energy of the reciprocal phase, it is necessary to give an arbitrary

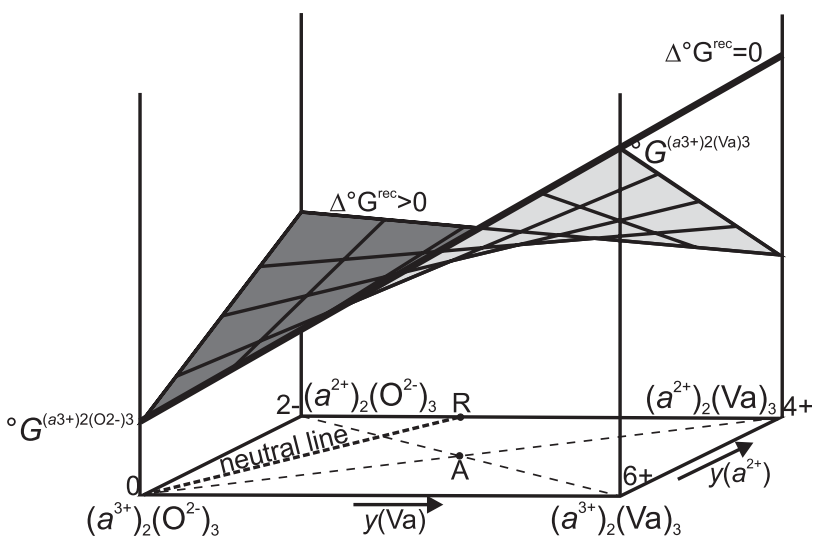

FIG. 1. The surface of reference for the Gibbs energy of the reciprocal phase $\left(a^{3+}, a^{2+}\right)_{2}\left(\mathrm{O}^{2-}, \mathrm{Va}\right)_{3}$ approximating its whole Gibbs energy for $\Delta^{\circ} G_{\text {rec }}>0$ and $\Delta^{\circ} G_{\text {rec }}=0$, plotted above the composition square. 
molar Gibbs energy to a reference. As the chosen molar Gibbs energy of the reference is unlikely the true value, the reference should favorably be a highly charged compound, thus far off neutral compositions that can really exist. For the example of the reciprocal solid solution phase $\left(a^{3+}, a^{2+}\right)_{2}\left(\mathrm{O}^{2-}, \mathrm{Va}\right)_{3}$, the $6+$ charged compound $\left(a^{3+}\right)_{2}(\mathrm{Va})_{3}$ is chosen as reference. The morphology of the Gibbs energy surface of the reciprocal phase depends on $\Delta^{\circ} G$ of the reciprocal reaction $\left(a^{3+}\right)_{2}(\mathrm{Va})_{3}+$ $\left(a^{2+}\right)_{2}\left(\mathrm{O}^{2-}\right)_{3}-\left(a^{3+}\right)_{2}\left(\mathrm{O}^{2-}\right)_{3}-\left(a^{2+}\right)_{2}(\mathrm{Va})_{3}$ :

$$
\begin{aligned}
\Delta G^{\mathrm{rec}}= & { }^{\circ}\left(a^{3+}\right)_{2}(\mathrm{Va})_{3} \\
& +{ }^{\circ} G^{\left(a^{2+}\right)_{2}\left(\mathrm{O}^{2-}\right)_{3}} \\
& -G^{\left(a^{3+}\right)_{2}\left(\mathrm{O}^{2-}\right)_{3}}-{ }^{\circ} G^{\left(a^{2+}\right)_{2}(\mathrm{Va})_{3}}
\end{aligned}
$$

The Gibbs energy surface of the reciprocal phase $\left(a^{3+}, a^{2+}\right)_{2}\left(\mathrm{O}^{2-}, \mathrm{Va}\right)_{3}$ resulting from $\Delta G_{\text {rec }}=0$, by neglecting the configurational entropy contribution, and without excess terms for the Gibbs energy is flat. The edge of this plane appears as bold line in Fig. 1. When on the other hand positive $\Delta G_{\text {rec }}$ is resulting from the modeling, the Gibbs energy surface is curved. The theoretic compound A will tend to demix to $\left(a^{3+}\right)_{2}\left(\mathrm{O}^{2-}\right)_{3}$ and $\left(a^{2+}\right)_{2}(\mathrm{Va})_{3}$ by only slightly oxidizing or reducing it. As no tendency of demixing was reported for the nonstoichiometric oxide solid solutions that are treated in this study, and no experiments define a proper value of the reciprocal reaction parameter, it is legitimate to define $\Delta G_{\text {rec }}=0$.

\section{Calculation of defect chemistry using the CALPHAD approach}

The CALPHAD method is powerful for the calculation of the defect chemistry of high-order nonstoichiometric reciprocal solid solution oxide phases ${ }^{14}$ such as (A)(B) $\mathrm{O}_{3-\delta}$ perovskite with a complex sublattice formula, for instance $\left(a^{3+}, b^{2+}, \mathrm{Va}\right)\left(c^{2+}, c^{3+}, c^{4+}, d^{3+}, d^{4+}, \mathrm{Va}\right)$ $\left(\mathrm{O}^{2-}, \mathrm{Va}\right)_{3}$ for Cr-doped LSM perovskite as a function of composition, temperature, and oxygen partial pressure, once model parameters of the reduced and oxidized compounds are optimized with experimental information on charge carriers, site fractions, and oxygen content.

\section{ASSESSMENT OF OXIDE SUBSYSTEMS}

Establishing of correct Gibbs energies polynomials of the oxide phases of the pseudoquaternary $\mathrm{La}-\mathrm{Sr}-\mathrm{Mn}-\mathrm{Cr}-\mathrm{O}$ oxide system requires thermodynamic assessments of experimental thermodynamic and phase diagram data of all oxide subsystems. Based on this assessment procedure, thermodynamic parameters were optimized using the PARROT data evaluation module of the ThermoCalc ${ }^{15}$ software (version S). PARROT can take into account all sorts of thermodynamic and phase diagram data simultaneously. The program minimizes the sum of squared errors between the experimentally determined phase diagram and thermodynamic data. As the use of all the experimental data in a simultaneous least square calculation often leads to divergence, the authors selectively adjusted the relative weight of each experimental data point and excluded data that were inconsistent with the majority of the data points during the optimization procedure. This weighting process is based on the accurate assessment of experimental thermodynamic and phase diagram data.

For the construction of the $\mathrm{La}-\mathrm{Sr}-\mathrm{Mn}-\mathrm{Cr}-\mathrm{O}$ oxide database, the $\mathrm{Sr}-\mathrm{Cr}$ oxide, $\mathrm{La}-\mathrm{Mn}-\mathrm{Cr}-\mathrm{O}$ oxide, and $\mathrm{La}-\mathrm{Sr}-\mathrm{Cr}-\mathrm{O}$ oxide systems are assessed. $\mathrm{Sr}-\mathrm{Mn}-\mathrm{Cr}-\mathrm{O}$ oxide is treated as ideal extension from the subsystems. No quaternary phases or solid solutions were found in the $\mathrm{Sr}-\mathrm{Mn}-\mathrm{Cr}-\mathrm{O}$ oxide system. ${ }^{16}$ Previous assessments of the $\mathrm{La}-\mathrm{O}, \mathrm{Cr}-\mathrm{O}$, $\mathrm{La}-\mathrm{Cr}-\mathrm{O}$, and $\mathrm{Cr}-\mathrm{Mn}-\mathrm{O}$ oxide databases are adopted from Povoden et al., ${ }^{17-21}$ with some modifications denoted in the supplement file to this paper, LSCM_v1.0.tcm (ThermoCalc macrofile), and the $\mathrm{La}-\mathrm{Sr}-\mathrm{Mn}-\mathrm{O}$ oxide database is taken from Grundy et al., ${ }^{22-27}$ also with the following slight modification: Grundy et al. ${ }^{23,24}$ allowed $\mathrm{Mn}^{3+}$ on the A-site of LSM to reproduce experimental oxygen nonstoichiometries under low oxygen partial pressures. Due to large differences between the ionic radii of $\mathrm{La}^{3+}$ and $\mathrm{Mn}^{3+}$ and possible coordination numbers $(1.5 \AA$ for 12 -fold coordinated $\mathrm{La}^{3+}, 0.785 \AA$ for at maximum 6-fold coordinated $\left.\mathrm{Mn}^{3+}\right),{ }^{28}$ we omit $\mathrm{Mn}^{3+}$ on the A-site. With this manipulation of the original model, still the results of calculated oxygen nonstoichiometry of LSM perovskite in equilibrium with $\mathrm{MnO}$ compare well with experimental data. ${ }^{27}$

\section{A. $\mathrm{Sr}-\mathrm{Cr}$-oxide}

Thermodynamic functions for $\mathrm{Sr}-\mathrm{Cr}$-oxides in the Scientific Group Thermodata Europe Substances Database $(\mathrm{SSUB})^{29}$ are based on estimates. ${ }^{30} \mathrm{We}$ propose optimized thermodynamic functions for oxide phases of the $\mathrm{Sr}-\mathrm{Cr}-\mathrm{O}$ oxide system resulting from the assessment of all available experimental data: agreement exists between Gibbs energies of formation of $\mathrm{SrCrO}_{4}$ determined by emf technique using a $\mathrm{Y}_{2} \mathrm{O}_{3}$-stabilized $\mathrm{ZrO}_{2}$ electrolyte, ${ }^{31,32}$ whereas emf measurements using $\mathrm{CaF}_{2}$-based emf technique ${ }^{33}$ led to conflicting results likely caused by competing reactions. ${ }^{34}$ Differences concern the reported stabilities of further compounds ${ }^{31,32,35-39}$ : for the stabilities of $\mathrm{SrCr}_{2} \mathrm{O}_{4}$ and $\mathrm{Sr}_{2} \mathrm{CrO}_{4}$, we trust the accurate study of Jacob and Abraham. ${ }^{31}$ On the other hand, the conflicting phase equilibria presented by Kisil et al. ${ }^{35}$ lack experimental details. $\mathrm{Sr}_{3} \mathrm{Cr}_{2} \mathrm{O}_{7}{ }^{32}$ was approved as high-pressure phase only. ${ }^{36}$ The stoichiometry of a phase defined as $\mathrm{Sr}_{3} \mathrm{Cr}_{2} \mathrm{O}_{8}{ }^{37}$ was later corrected to be essentially $\mathrm{Sr}_{2.67} \mathrm{Cr}_{2} \mathrm{O}_{8}$ by using microprobe analysis, ${ }^{38}$ in agreement with Hartl and Braungart. ${ }^{39}$ 


\section{B. La-Sr-Cr-oxide}

In the $\mathrm{La}-\mathrm{Sr}-\mathrm{Cr}-\mathrm{O}$ oxide systems, no quaternary stoichiometric compounds were reported. Phase equilibria in the $\mathrm{La}-\mathrm{Sr}-\mathrm{Cr}-\mathrm{O}$ oxide system in air at $1223 \mathrm{~K}$ and under vacuum at $1873 \mathrm{~K}$ were determined by using solidstate technique. ${ }^{5}$ Limited solution of $\mathrm{Sr}$ in $\mathrm{La}_{1-x} \mathrm{Sr}_{x} \mathrm{CrO}_{3-\delta}$ perovskite was confirmed by a later investigation. ${ }^{40}$

The existence of several layered phases of the Ruddlesden-Popper series with alternating perovskite and rocksalt structure units ${ }^{41}$ is restricted to reducing conditions; solely, $\mathrm{Sr}(\mathrm{La}, \mathrm{Sr}) \mathrm{CrO}_{4}$ showed reproducible stoichiometry. ${ }^{38}$ In contrast to Peck et al., ${ }^{38}$ it was proposed earlier that $\mathrm{Sr}(\mathrm{La}, \mathrm{Sr}) \mathrm{CrO}_{4}$ were stable in air. ${ }^{30}$ The exact temperature and oxygen partial pressure range of $\mathrm{Sr}(\mathrm{La}, \mathrm{Sr}) \mathrm{CrO}_{4}$ is ambiguous, thermodynamic data are missing, and the solubility of $\mathrm{Cr}$ is unknown. Thus, and since Ruddlesden-Popper phases have not been reported to form during SOFC operation with LSM cathodes, $\mathrm{Sr}(\mathrm{La}, \mathrm{Sr}) \mathrm{CrO}_{4}$ is omitted in the modeling at present.

Myoshi et al. ${ }^{40}$ investigated the single-phase region of $\mathrm{La}_{1-x} \mathrm{Sr}_{x} \mathrm{CrO}_{3}$ with $x=0.1,0.2$, and 0.3 as a function of temperature and oxygen partial pressure using $\mathrm{x}$-ray diffraction analysis. Peck ${ }^{42}$ determined the Gibbs energy of formation of $\mathrm{La}_{1-x} \mathrm{Sr}_{x} \mathrm{CrO}_{3}$ with $x=0.1,0.2$, and 0.3 using Knudsen mass spectrometry. Cheng and Navrotsky ${ }^{43}$ measured enthalpies of formation of $\mathrm{La}_{1-x} \mathrm{Sr}_{x} \mathrm{CrO}_{3-\delta}$ with $x=0.1,0.2$, and 0.3 , and $\delta=0$, $-0.04,-0.09$, and -0.11 using drop calorimetry at $1080 \mathrm{~K}$. Positive $\delta$ in the perovskite formula reflects oxygen deficiency, whereas negative $\delta$ essentially stands for cation nonstoichiometriy. Nonstoichiometry data for $\mathrm{La}_{1-x} \mathrm{Sr}_{x} \mathrm{CrO}_{3-\delta}$ with $x=0.1,0.2$, and 0.3 at 1273,1373 , 1473 , and $1573 \mathrm{~K},{ }^{44}$ and $\mathrm{La}_{0.8} \mathrm{Sr}_{0.2} \mathrm{CrO}_{3-\delta}$ at $1273 \mathrm{~K}^{45}$ were measured as a function of oxygen partial pressure using thermogravimetry. $\mathrm{Cr}^{4+}$ and oxygen vacancies are regarded as the major defects. ${ }^{44,45}$

\section{La-Mn-Cr-oxide system}

As in the $\mathrm{La}-\mathrm{Sr}-\mathrm{Cr}-\mathrm{O}$ oxide system, quaternary stoichiometric compounds are missing. An isothermal section of the $\mathrm{La}-\mathrm{Mn}-\mathrm{Cr}-\mathrm{O}$ oxide system at $1073 \mathrm{~K}$ in air and pure oxygen has been published without further commenting of experimental evidences. ${ }^{46}$ Complete solid solution between the $\mathrm{LaMnO}_{3}$ and the $\mathrm{LaCrO}_{3}$ perovskites was affirmed. ${ }^{17} \delta$ of $\mathrm{LaMn}_{0.9} \mathrm{Cr}_{0.1} \mathrm{O}_{3-\delta}$ was measured using thermogravimetry. ${ }^{47}$

\section{La-Sr-Mn-Cr-oxide system}

In the $\mathrm{La}-\mathrm{Sr}-\mathrm{Mn}-\mathrm{Cr}-\mathrm{O}$ oxide system, complete solid solubility of $\mathrm{Mn}$ and $\mathrm{Cr}$ is reported for $\mathrm{La}_{1-x} \mathrm{Sr}_{x} \mathrm{Mn}_{1-y} \mathrm{Cr}_{y} \mathrm{O}_{3-\delta}$ perovskite. ${ }^{17}$ Plint et al. ${ }^{48}$ concluded from the similarity between x-ray absorbtion spectra of $\mathrm{Cr} \mathrm{K}$ of $\mathrm{LaCrO}_{3}$ and $\mathrm{La}_{1-x} \mathrm{Sr}_{x} \mathrm{Mn}_{0.5} \mathrm{Cr}_{0.5} \mathrm{O}_{3-\delta}$ with $x=0.2,0.25$, and 0.3 at $1173 \mathrm{~K}$-edges that $\mathrm{Cr}^{4+}$ were absent in the latter.
Perovskite $+\mathrm{MnCr}_{2} \mathrm{O}_{4}$ spinel equilibrium of a powdered mixture of $\mathrm{La}_{0.8} \mathrm{Sr}_{0.2} \mathrm{MnO}_{3}$ and $\mathrm{Cr}_{2} \mathrm{O}_{3}$ at $1073 \mathrm{~K}$ was reported after $1000 \mathrm{~h}$ of heat treatment in air ${ }^{49}$.

\section{THERMODYNAMIC DESCRIPTIONS OF OXIDE PHASES}

\section{A. $\mathrm{Sr}-\mathrm{Cr}$-oxide}

The sublattice models $\left(\mathrm{Sr}^{2+}\right)\left(\mathrm{Cr}^{6+}\right)\left(\mathrm{O}^{2-}\right)_{4}$ and $\left(\mathrm{Sr}^{2+}\right)$ $\left(\mathrm{Cr}^{3+}\right)_{2}\left(\mathrm{O}^{2-}\right)_{4}$ are used for the descriptions of $\mathrm{SrCrO}_{4}$ and $\mathrm{SrCr}_{2} \mathrm{O}_{4} \cdot\left(\mathrm{Sr}^{2+}\right)_{8 / 3}(\mathrm{Vaa})_{1 / 3}\left(\mathrm{Cr}^{6+}\right)_{2 / 3}\left(\mathrm{O}^{2-}\right)_{8 / 3}\left(\mathrm{Cr}^{5+}\right)_{4 / 3}$ $\left(\mathrm{O}^{2-}\right)_{16 / 3}$ and $\left(\mathrm{Sr}^{2+}\right)\left(\mathrm{O}^{2-}\right)_{1}\left(\mathrm{Sr}^{2+}\right)\left(\mathrm{Cr}^{4+}\right)\left(\mathrm{O}^{2-}\right)_{3}$ were chosen for $\mathrm{Sr}_{2.67} \mathrm{Cr}_{2} \mathrm{O}_{8}$ following the proposed formula ${ }^{39}$ and for the Ruddlesden-Popper phase $\mathrm{Sr}_{2} \mathrm{CrO}_{4}$, accounting for the structural feature of alternating rocksalt and perovskite layers of the latter. Gibbs energy functions of $\mathrm{Sr}-\mathrm{Cr}$-oxides were formulated as

$$
\begin{aligned}
& { }^{\circ} G_{(\mathrm{Sr}) x(\mathrm{Cr}) y(\mathrm{O}) z}-x H_{\mathrm{Sr}}^{\mathrm{SER}}-y H_{\mathrm{Cr}}^{\mathrm{SER}}-z H_{\mathrm{O}}^{\mathrm{SER}} \\
& =x^{\circ} G_{\mathrm{SrO}}{ }^{\text {Ref. } 48}+\frac{1}{2} y^{\circ} G_{\mathrm{Cr} 2 \mathrm{O} 3}{ }^{\text {Ref. } 19} \\
& \quad+v^{\circ} G_{\mathrm{O}_{2}}^{\text {gas Ref } 9}+A+B T,
\end{aligned}
$$

where $v=0.75,0,7 / 6$, and 0.25 for $\mathrm{SrCrO}_{4}, \mathrm{SrCr}_{2} \mathrm{O}_{4}$, $\mathrm{Sr}_{2.67} \mathrm{Cr}_{2} \mathrm{O}_{8}$, and $\mathrm{Sr}_{2} \mathrm{CrO}_{4}$, respectively. $H_{a}^{\mathrm{SER}}$ is the standard enthalpy of the stable state of element $a$ at $298.15 \mathrm{~K}$ and $10^{5} \mathrm{~Pa}^{50}$

\section{B. Modeling of the perovskite phase}

It is essential for a consistent description of the perovskite phase that defects that occur in the structure in low-order systems remain on the same sites at the extension to higher order; this is achieved by using the same model. We adopt the description $(\mathrm{A}, \mathrm{Va})(\mathrm{B}, \mathrm{Va})\left(\mathrm{O}^{-2}, \mathrm{Va}\right)_{3}$ with $\mathrm{A}, \mathrm{B}=$ cations, and $\mathrm{Va}=$ vacancies $^{23,24}$ using the $\mathrm{CEF}^{12}$ and the concept of reciprocal reactions described in Sec. I. B. 3. The molar Gibbs energy of the perovskite phase then reads

$$
\begin{aligned}
{ }^{\circ} G_{\mathrm{m}}^{\mathrm{prv}}= & \sum_{i} \sum_{j} \sum_{k} y_{i} y_{j} y_{k} G_{i: \mathrm{j}: k} \\
& +R T\left(\sum_{i} y_{i} \ln y_{i}+\sum_{j} y_{j} \ln y_{j}+3 \sum_{k} y_{k} \ln y_{k}\right) \\
& +{ }^{\mathrm{E}} G_{\mathrm{m}}^{\mathrm{prv}}
\end{aligned}
$$

where $y_{i}$ is the site fraction of each cation and Va on the A-sublattice, $y_{j}$ is the site fraction of each cation and $\mathrm{Va}$ on the B-sublattice, and $y_{k}$ is the site fraction of $\mathrm{O}^{2-}$ and $\mathrm{Va}$ on the anion sublattice. $R=8.31451 \mathrm{~J} /(\mathrm{mol} \mathrm{K})$. The second last term accounts for the configurational entropy of mixing. The last term describes the excess Gibbs energy 
of mixing. It can be accounted for by introducing interaction parameters. The parameters of the CEF are the Gibbs energies of the end-member compounds ${ }^{\circ} G_{i j:: k}$. Typical compositions of LSMs used for SOFC cathodes, e.g., $\mathrm{La}_{0.8} \mathrm{Sr}_{0.2} \mathrm{MnO}_{3-\delta}$ are rhombohedral at SOFC operating temperatures (1073-1273 K), and small amounts of $\mathrm{Cr}$ brought into the cathode unlikely lead to a change of the structure. Thus, to meet applicability of the database, it is reliable to take the Gibbs energies of the compounds of rhombohedral perovskite from Ref. 20 for the model. By doing so, we realized that the original temperaturedependent terms of GS4O and GS3V stabilize $\mathrm{SrCrO}_{3}$ perovskite at high temperatures. This problem is solved with modified parameters listed in the supplement LSCM_v1.0.tcm.

\section{1. $\mathrm{La}_{1-x} \mathrm{Sr}_{x} \mathrm{CrO}_{3-\delta}$ perovskite}

Using the above model and the proposed defect chemistry, ${ }^{43-45}$ the sublattice formula for $\mathrm{La}_{1-x} \mathrm{Sr}_{x} \mathrm{CrO}_{3-\delta}$ reads $\left(\mathrm{La}^{3+}, \mathrm{Sr}^{2+}, \mathrm{Va}\right)\left(\mathrm{Cr}^{3+}, \mathrm{Cr}^{4+}, \mathrm{Va}\right)\left(\mathrm{O}^{2-}, \mathrm{Va}\right)_{3}$. The molar Gibbs energy ${ }^{\circ} G$ of $\mathrm{La}_{1-x} \mathrm{Sr}_{x} \mathrm{CrO}_{3-\delta}$ is uniquely defined as follows: ${ }^{\circ} \mathrm{G}$ s of the end-members $\left(\mathrm{La}^{3+}\right)\left(\mathrm{Cr}^{3+}\right)$ $\left(\mathrm{O}^{2-}\right)_{3}, \quad\left(\mathrm{La}^{3+}\right)\left(\mathrm{Cr}^{3+}\right)(\mathrm{Va})_{3}, \quad\left(\mathrm{La}^{3+}\right)(\mathrm{Va})\left(\mathrm{O}^{2-}\right)_{3}, \quad\left(\mathrm{La}^{3+}\right)$ $(\mathrm{Va})(\mathrm{Va})_{3},\left(\mathrm{Sr}^{2+}\right)(\mathrm{Va})\left(\mathrm{O}^{2-}\right)_{3},\left(\mathrm{Sr}^{2+}\right)(\mathrm{Va})(\mathrm{Va})_{3},(\mathrm{Va})(\mathrm{Va})$ $\left(\mathrm{O}^{2-}\right)_{3}$, and $(\mathrm{Va})(\mathrm{Va})(\mathrm{Va})_{3}$ and ternary interaction parameters are adopted, ${ }^{20,24,52}{ }^{\circ} \mathrm{G}\left(\mathrm{Sr}^{2+}\right)\left(\mathrm{Cr}^{4+}\right)(\mathrm{Va})_{3}$

$$
\begin{aligned}
{ }^{\circ} G_{\mathrm{SrCrVa}_{3}}-H_{\mathrm{Sr}}^{\mathrm{SER}}-H_{\mathrm{Cr}}^{\mathrm{SER}}= & { }^{\circ} G_{\mathrm{Sr}^{2+}: \mathrm{Cr}^{4+}: \mathrm{Va}}=G S 4 V \\
= & G_{\mathrm{SrO}}{ }^{\operatorname{Ref} .50}+\frac{1}{2}{ }^{\circ} G_{\mathrm{Cr}_{2} \mathrm{O}_{3}}{ }^{\text {Ref. } 19} \\
& -\frac{5}{4} G^{\circ} G_{\mathrm{O}_{2}}^{\text {gas Ref. } 9}
\end{aligned}
$$

is chosen as reference, and ${ }^{\circ} G$ of two neutral compounds read

$$
\begin{aligned}
& { }^{\circ} G_{\mathrm{SrCrO}_{3}}-H_{\mathrm{Sr}}^{\mathrm{SER}}-H_{\mathrm{Cr}}^{\mathrm{SER}}-3 H_{\mathrm{O}}^{\mathrm{SER}} \\
& ={ }^{\circ} G_{\mathrm{Sr}^{2+}: \mathrm{Cr}^{4+}: \mathrm{O}^{2-}}=\mathrm{GS} 4 \mathrm{O} \\
& ={ }^{\circ} G_{\mathrm{SrO}}{ }^{\mathrm{Ref} .49}+\frac{1}{2}{ }^{\circ} G_{\mathrm{Cr}_{2} \mathrm{O}_{3}}{ }^{\operatorname{Ref} .19}+\frac{1}{4}{ }^{\circ} G_{\mathrm{O}_{2}}^{\text {gasRef. } 9} \\
& \quad+A+B T,
\end{aligned}
$$

$$
\begin{aligned}
& { }^{\circ} G_{\mathrm{SrCrO}_{2.5} \mathrm{Va}_{0} .5}-H_{\mathrm{Sr}}^{\mathrm{SER}}-H_{\mathrm{Cr}}^{\mathrm{SER}}-2.5 H_{\mathrm{O}}^{\mathrm{SER}} \\
& =\mathrm{GS} 3 \mathrm{~V}=\frac{5}{6} G_{\mathrm{Sr}^{2+}: \mathrm{Cr}^{3+}: \mathrm{O}^{2-}}+\frac{1}{6}{ }^{\circ} G_{\mathrm{Sr}^{2+}: \mathrm{Cr}^{3+}: \mathrm{Va}} \\
& +R T\left(\frac{5}{6} \ln \frac{5}{6}+\frac{1}{6} \ln \frac{1}{6}\right) \\
& ={ }^{\circ} G_{\mathrm{SrO}}{ }^{\operatorname{Ref} .50}+\frac{1}{2}{ }^{\circ} G_{\mathrm{Cr}_{2} \mathrm{O}_{3}}{ }^{\operatorname{Ref} .19}+A+B T
\end{aligned}
$$

\section{2. $\mathrm{LaMn}_{1-x} \mathrm{Cr}_{x} \mathrm{O}_{3-\delta}$ perovskite}

Though structure-chemical information of site occupancies in $\mathrm{LaMn}_{1-x} \mathrm{Cr}_{x} \mathrm{O}_{3-\delta}$ perovskite is missing, it is reliable to allow $\mathrm{Cr}^{4+}$ on the B-site: since $\mathrm{Cr}^{4+}$ exists in nonstoichiometric lanthanum chromite perovskite, ${ }^{20}$ it is expected that it is not removed from the structure if the phase is doped. Thus, for $\mathrm{LaMn}_{1-x} \mathrm{Cr}_{x} \mathrm{O}_{3-\delta}$, we propose the sublattice formula $\left(\mathrm{La}^{3+}, \mathrm{Va}\right)\left(\mathrm{Mn}^{2+}, \mathrm{Mn}^{3+}, \mathrm{Mn}^{4+}\right.$, $\left.\mathrm{Cr}^{3+}, \mathrm{Cr}^{4+}, \mathrm{Va}\right)\left(\mathrm{O}^{2-}, \mathrm{Va}\right)_{3}$.

\section{Modeling of $\mathrm{Cr}^{4+}$ in LSCM perovskite}

The sublattice formula of the quinary perovskite reads $\left(\mathrm{La}^{3+}, \mathrm{Sr}^{2+}, \mathrm{Va}\right)\left(\mathrm{Mn}^{2+}, \mathrm{Mn}^{3+}, \mathrm{Mn}^{4+}, \mathrm{Cr}^{3+}, \mathrm{Cr}^{4+}, \mathrm{Va}\right)$ $\left(\mathrm{O}^{2-}, \mathrm{Va}\right)_{3}$. All end-members have been defined in the assessed subsystems.

To approximate the absence of $\mathrm{Cr}^{4+}, 48$ it would be necessary to give large positive values to the regular [i.e., independent of $x(\mathrm{Cr})$ and $x(\mathrm{Mn})$ in LSCM] interaction parameters ${ }^{0} L\left(\mathrm{Sr}^{2+}: \mathrm{Cr}^{3+}, \mathrm{Mn}^{3+}: \mathrm{O}^{2-}\right)$ and ${ }^{0} L\left(\mathrm{Sr}^{2+}: \mathrm{Cr}^{4+}\right.$, $\left.\mathrm{Mn}^{3+}: \mathrm{O}^{2-}\right)$. Experimentally determined nonstoichiometry of $\mathrm{LaCrO}_{3}$ indicates the existence of some $\mathrm{Cr}^{4+}$, and the conclusion of missing $\mathrm{Cr}^{4+}$ (Ref. 49) is not based on a direct chemical analysis of $\mathrm{Cr}$ valencies. We believe that complete removal of $\mathrm{Cr}^{4+}$ from the perovskite structure is unlikely. Thus, we stick to a model without interaction parameters. Experimental findings ${ }^{16,48}$ are in line with our calculations.

\section{OPTIMIZATION RESULTS AND DISCUSSION}

The assessed Gibbs energies of the $\mathrm{La}-\mathrm{Sr}-\mathrm{Cr}-\mathrm{Mn}-\mathrm{O}$ oxide database, LSCM_v1.0, are laid open in the supplement to this paper.

\section{A. Parameterization of thermodynamic parameters of the $\mathrm{Sr}-\mathrm{Cr}-\mathrm{O}$ oxide system}

$A$ and $B$ of Eq. (9) are adjustable parameters; their optimization with the following experimental phase diagram and thermodynamic data using the PARROT module of the ThermoCalc software ${ }^{16}$ resulted in the lowest error between model and experiments: Gibbs energies of formation of $\mathrm{SrCrO}_{4}{ }^{31,32}$ and phase stabilities of $\mathrm{SrCr}_{2} \mathrm{O}_{4}$ and $\mathrm{Sr}_{2} \mathrm{CrO}_{4}$ investigated by equilibration experiments of different mixed oxide compositions under controlled atmospheres ${ }^{31}$ and the equilibrium $\mathrm{Sr}_{2.67} \mathrm{Cr}_{2} \mathrm{O}_{8}+\mathrm{SrCrO}_{4}$ $+\mathrm{Cr}_{2} \mathrm{O}_{3}$ as a function of temperature and oxygen partial pressure. $^{31,32}$ The reported subsolidus phase equilibria ${ }^{31}$ are correctly reproduced by the model, as shown in Fig. 2 .

Since both experimental thermodynamic and phase diagram data are available for the optimization of $\mathrm{Sr}-\mathrm{Cr}-\mathrm{O}$ oxide $\mathrm{SrCrO}_{4}$ and $\mathrm{Sr}_{2.67} \mathrm{Cr}_{2} \mathrm{O}_{8}$ descriptions, we believe that the predicted thermodynamics is close to the real 


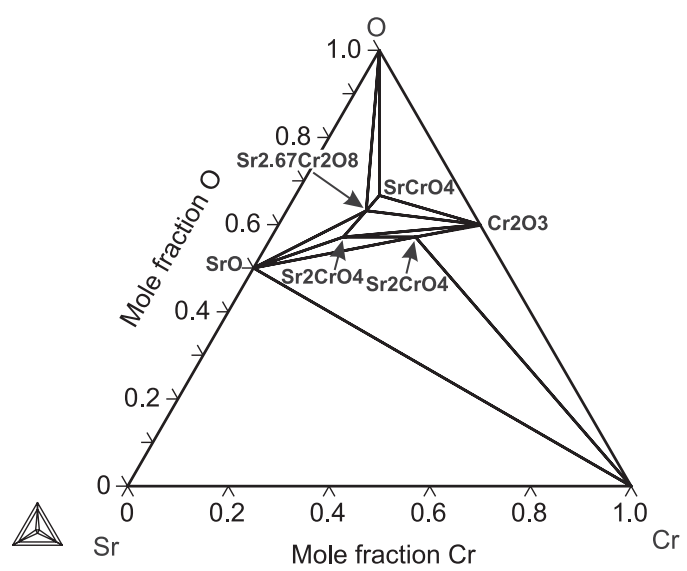

FIG. 2. Calculated isothermal $\mathrm{Sr}-\mathrm{Cr}-\mathrm{O}$ section at $1250 \mathrm{~K}$. The same three-phase equilibria are predicted as experimentally observed. ${ }^{31}$ situation. However, to confirm the quality of the modeling, further experimental work, in particular calorimetry, would be beneficial to directly obtain enthalpy data of $\mathrm{Sr}-\mathrm{Cr}-\mathrm{O}$ oxide phases. Also, differential scanning calorimetry is suggested to testify their thermal stabilities. $\mathrm{SrCr}_{2} \mathrm{O}_{4}$ and $\mathrm{Sr}_{2} \mathrm{CrO}_{4}$, which are stable under reducing conditions, are solely optimized by experimental phase diagram data. Thus, their descriptions are considered tentative, as long as no experimental thermodynamic data are available.

Our modeling predicts the high temperature phase equilibria that include the liquid phase, proposed by Negas and Roth, ${ }^{37}$ not exactly. This becomes evident in Fig. 3, showing the calculated $\mathrm{SrO}-\mathrm{Cr}_{2} \mathrm{O}_{3}$ in air atmosphere (a), in comparison with experiments (b), and in oxygen (c) with experimental data included. Since Negas and Roth $^{37}$ report hydroxide formation in the humid air

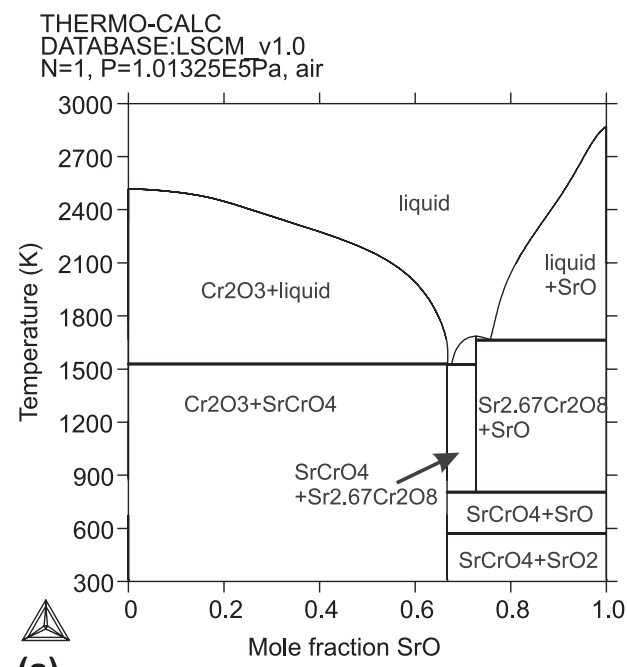

(a)

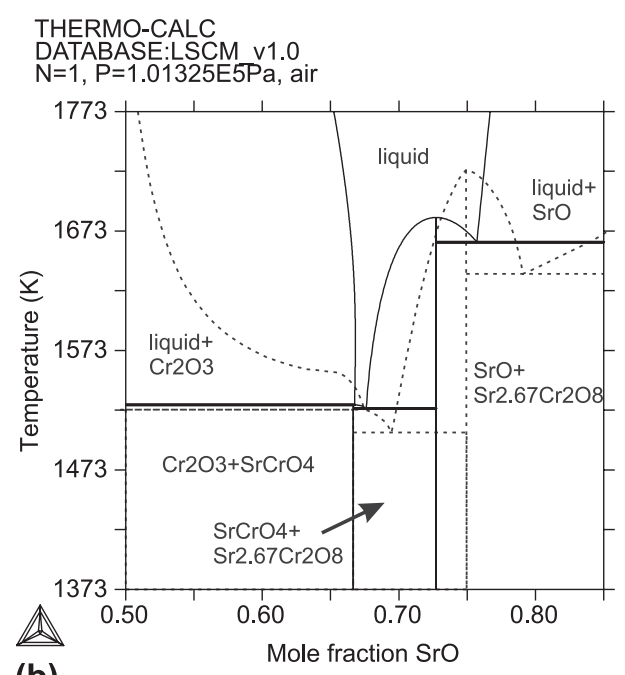

(b)

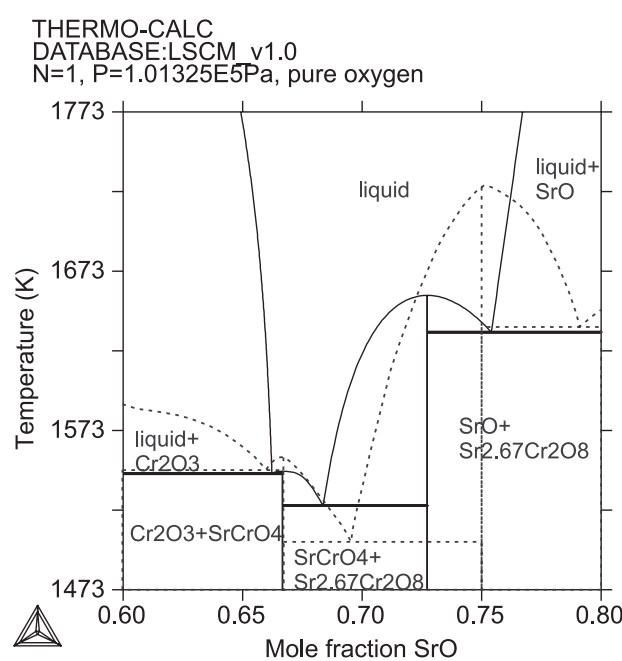

(c)

FIG. 3. $\mathrm{SrO}-\mathrm{Cr}_{2} \mathrm{O}_{3}$ system calculated (solid lines) in air atmosphere (a), and region of intermetallic phases in air (b) and oxygen (c) with experimental data (dashed lines) ${ }^{37}$ included. 
atmosphere during their experiments, it is rather sensible not to overvalue their results for the parameter optimization of water-free $\mathrm{SrO}-\mathrm{Cr}_{2} \mathrm{O}_{3}$. A better reproduction of the experimental phase equilibria proposed by Negas and Roth,${ }^{37}$ by manipulating the model parameters of solid oxides, will lead to a worse reproduction of both the newer thermodynamic and phase diagram data. ${ }^{31,32}$ On the other hand, the chosen liquid description allows at least for qualitative reproduction of experimental phase equilibria.

A specific feature of this system is the deep eutectic at $70 \mathrm{~mol} \% \mathrm{SrO}$ and the rather flat liquidus curves toward high $\mathrm{Cr}_{2} \mathrm{O}_{3}$ and $\mathrm{SrO}$ values, respectively. The ionic liquid model $^{51,52}$ has been used for the liquid description. Strategies of liquid modeling are discussed in detail in the assessments of binary subsystems. ${ }^{17,19,50}$ The experimental liquidus course indicates strong deviation from ideal mixing, which requires a complex model description. In addition to end-member ionic species, in the current liquid description of $\mathrm{SrO}-\mathrm{Cr}_{2} \mathrm{O}_{3}$, intermediate liquid associates ${ }^{53,54}$ are necessary. The neutral associate $\mathrm{SrCrO}_{4}$ is chosen to simulate $\mathrm{Cr}^{6+}$ in the liquid, and $\mathrm{SrCrO}_{3}$ reflects the existence of $\mathrm{Cr}^{4+}$. Temperature dependence of interaction parameters is neglected since this makes them less controllable in terms of their extensions to high orders. For instance, the liquid phase might appear at low temperatures, or artificial miscibility gaps may occur. For the time being, we make do with a qualitative liquidus reproduction, as the liquid phase, being not essential for production and working temperatures of SOFC, is not a focus of this study. The modified quasichemical model, ${ }^{55}$ allowing for shortrange order in the liquid description, will potentially improve the reproduction of the experimental liquidus.

\section{B. Perovskite-parameterization of thermodynamic model parameters}

\section{1. $\mathrm{La}_{1-x} \mathrm{Sr}_{x} \mathrm{CrO}_{3-\delta}$}

$A$ and $B$ parameters of the neutral perovskite compounds GS4O and GS3V from Eqs. (12) and (13), respectively, are optimized with all available experimental data of the perovskite phase. Eq. (12) denotes ${ }^{\circ} G\left(\mathrm{Sr}^{2+}\right)\left(\mathrm{Cr}^{4+}\right)$ $\left(\mathrm{O}^{2-}\right)_{3}$, with $A=+30,800$ and $B=-40 . A=+140$, 300 and $B=-67$ for ${ }^{\circ} G_{\mathrm{SrCr}_{02.5} \mathrm{Va}_{0.5}}$ in Eq. (13). ${ }^{\circ} G$ s of the remaining end-members $\left(\mathrm{La}^{3+}\right)\left(\mathrm{Cr}^{4+}\right)(\mathrm{Va})_{3},\left(\mathrm{La}^{3+}\right)$ $\left(\mathrm{Cr}^{4+}\right)\left(\mathrm{O}^{2-}\right)_{3}, \quad\left(\mathrm{Sr}^{2+}\right)\left(\mathrm{Cr}^{3+}\right)\left(\mathrm{O}^{2-}\right)_{3}$, and $\left(\mathrm{Sr}^{2+}\right)\left(\mathrm{Cr}^{3+}\right)$ $(\mathrm{Va})_{3}$ are obtained by conversions of reciprocal equations that are set zero ${ }^{23}$ and are listed in Table I. The solution of $\mathrm{Sr}$ in $\mathrm{La}_{1-x} \mathrm{Sr}_{x} \mathrm{CrO}_{3-\delta}$ is adjusted by negative interaction energies of $\mathrm{Sr}^{2+}$ and $\mathrm{La}^{3+}$ in the first sublattice.

The reproduction of experimentally determined Gibbs energies ${ }^{42}$ and enthalpies of formation, ${ }^{43}$ solid solubilities, ${ }^{38,40}$ and nonstoichiometries ${ }^{44,45}$ of $\mathrm{La}_{1-x} \mathrm{Sr}_{x} \mathrm{CrO}_{3-\delta}$ as well as phase equilibria in the $\mathrm{La}-\mathrm{Sr}-\mathrm{Cr}-\mathrm{O}$ oxide system by the modeling is satisfying as shown in Table II and in Figs. 4 and 5. Due to the availability of various types of experimental data, which can be used for the parameter optimization, the model description in principle appears reliable. Experimental phase equilibria of the experimental isothermal section at $1223 \mathrm{~K}$ are reproduced by the model. Potential improvement of the modeling will become accessible, when also the extension of calculated phase equilibria toward higher temperatures can be based on experimental phase equilibria.

The error between calculated and experimental molar enthalpies of the perovskite phase is in general less than $10 \%$. The higher difference of approximately $20 \%$ between calculated and experimental Gibbs energies is likely due to more error sources of the experimental gas phase equilibria method used. Calculated oxygen nonstoichiomteries at different $\mathrm{Sr}$ contents in perovskite are in principle closest to the experiments at higher temperatures from 1473 to

TABLE I. Optimized model parameters.

\begin{tabular}{l}
\hline \hline $\mathrm{Sr}-\mathrm{Cr}$ oxides \\
\hline$A_{\mathrm{SrCrO} 4}=-273,771 \mathrm{~J} ; B_{\mathrm{SrCrO} 4}=+131.6 \mathrm{~J}$ \\
$A_{\mathrm{Sr} 2 \mathrm{CrO} 4}=-145,000 \mathrm{~J} ; B_{\mathrm{Sr} 2 \mathrm{CrO} 4}=+50 \mathrm{~J}$ \\
$A_{\mathrm{SrCr} 204}=+20,000 \mathrm{~J} ; B_{\mathrm{SrCr} 2 \mathrm{O} 4}=-28 \mathrm{~J}$ \\
$A_{\mathrm{Sr} 2.67 \mathrm{Cr} 2 \mathrm{O} 8}=-508,507 \mathrm{~J} ; B_{\mathrm{Sr} 2.67 \mathrm{Cr} 2 \mathrm{O} 8}=+219 \mathrm{~J}$ \\
$\mathrm{La}_{1-x} \mathrm{Sr}_{x} \mathrm{CrO}_{3-\delta}$ \\
${ }^{\circ} G_{\mathrm{La}^{3+}: \mathrm{Cr}^{4+}: \mathrm{Va}}=5 / 6 \mathrm{GS} 4 \mathrm{O}-\mathrm{GS} 3 \mathrm{~V}+1 / 6 \mathrm{GS} 4 \mathrm{~V}+\mathrm{GRPRV}^{11}-1.5^{\circ} G_{\mathrm{O}_{2}}^{\mathrm{gas} 9}$ \\
${ }^{\circ} G_{\mathrm{La}^{3+}: \mathrm{Cr}^{4+}: \mathrm{O}^{2-}}=5 / 6 \mathrm{GS} 4 \mathrm{O}-\mathrm{GS} 3 \mathrm{~V}+1 / 6 \mathrm{GS} 4 \mathrm{~V}+\mathrm{GRPRV}^{11}$ \\
${ }^{\circ} G_{\mathrm{Sr}^{2+}: \mathrm{Cr}^{3+}: \mathrm{O}^{2-}}=\mathrm{GS} 3 \mathrm{~V}+1 / 6 \mathrm{GS} 4 \mathrm{O}-1 / 6 \mathrm{GS} 4 \mathrm{~V}$ \\
${ }^{\circ} \mathrm{Srr}^{\mathrm{Sr}^{+}: \mathrm{Cr}^{3+}: \mathrm{Va}}=\mathrm{GS} 3 \mathrm{~V}-5 / 6 \mathrm{GS} 4 \mathrm{O}+5 / 6 \mathrm{GS} 4 \mathrm{~V}$ \\
\hline \hline
\end{tabular}

TABLE II. Calculated and experimental thermodynamic data.

$\mathrm{SrO}+1 / 2 \mathrm{Cr}_{2} \mathrm{O}_{3}+3 / 4 \mathrm{O}_{2}=\mathrm{SrCrO}_{4}$

$\Delta^{\circ} G=-273.774+0.13152 T \mathrm{~kJ} / \mathrm{mol}$ this work, calc.

$\Delta^{\circ} G=-213.050+0.106904 T \mathrm{~kJ} / \mathrm{mol}, 851-1116 \mathrm{~K}^{33}$

$\Delta^{\circ} G=-273.825 \pm 0.2+0.13157 T \mathrm{~kJ} / \mathrm{mol}, 950-1280 \mathrm{~K}^{31}$

$\mathrm{Sr}_{2.67} \mathrm{Cr}_{2} \mathrm{O}_{8}+\mathrm{SrCrO}_{4}+\mathrm{Cr}_{2} \mathrm{O}_{3}$

$\Delta \mu \mathrm{O}_{2}=-265.859+0.15832 T \mathrm{~kJ} / \mathrm{mol}$ this work, calc.

$\Delta \mu \mathrm{O}_{2}=-262.340+0.15553 T \mathrm{~kJ} / \mathrm{mol}, 1073-1473 \mathrm{~K}^{32}$

$\Delta \mu \mathrm{O}_{2}=-276.767+0.166 \mathrm{~kJ} / \mathrm{mol}, 1080-1380 \mathrm{~K}^{31}$

$(1-x) / 2 \mathrm{La}_{2} \mathrm{O}_{3}+x \mathrm{SrO}+1 / 2 \mathrm{Cr}_{2} \mathrm{O}_{3}+x / 4 \mathrm{O}_{2}-\delta / 2 \mathrm{O}_{2}=\mathrm{La}_{1-x} \mathrm{Sr}_{x} \mathrm{CrO}_{3-\delta}$

$x=0.1, \delta=0, T=2000 \mathrm{~K}, \Delta^{\circ} G=-94.1 \mathrm{~kJ} / \mathrm{mol}$ this work, calc.

$\Delta \Delta^{\circ}=-85.7 \mathrm{~kJ} / \mathrm{mol}^{42}$

$x=0.2, \delta=0, T=2000 \mathrm{~K}, \Delta^{\circ} G=-102.5 \mathrm{~kJ} / \mathrm{mol}$ this work, calc.

$\Delta{ }^{\circ} G=-88.7 \mathrm{~kJ} / \mathrm{mol}^{42}$

$x=0.3, \delta=0, T=2000 \mathrm{~K}, \Delta^{\circ} G=-107.1 \mathrm{~kJ} / \mathrm{mol}$ this work, calc.

$\Delta{ }^{\circ} G=-93.5 \mathrm{~kJ} / \mathrm{mol}^{42}$

$x=0.1, \delta=0, T=298 \mathrm{~K}, \Delta{ }^{\circ} H=-63.4 \mathrm{~kJ} / \mathrm{mol}$ this work, calc.

$\Delta \Delta^{\circ} H=-67.88 \mathrm{~kJ} / \mathrm{mol}^{43}$

$x=0.1, \delta=0.04, T=298 \mathrm{~K}, \Delta^{\circ} H=-54.2 \mathrm{~kJ} / \mathrm{mol}$ this work, calc.

$\Delta{ }^{\circ} H=-59.15 \mathrm{~kJ} / \mathrm{mol}^{43}$

$x=0.2, \delta=0, T=298 \mathrm{~K}, \Delta^{\circ} H=-52.7 \mathrm{~kJ} / \mathrm{mol}$ this work, calc.

$\Delta H=-50.54 \mathrm{~kJ} / \mathrm{mol}^{43}$

$x=0.2, \delta=0.09, T=298 \mathrm{~K}, \Delta^{\circ} H=-32.3 \mathrm{~kJ} / \mathrm{mol}$ this work, calc.

$\Delta^{\circ} H=-34.76 \mathrm{~kJ} / \mathrm{mol}^{43}$

$x=0.3, \delta=0, T=298 \mathrm{~K}, \Delta^{\circ} H=-42.8 \mathrm{~kJ} / \mathrm{mol}$ this work, calc.

$\Delta{ }^{\circ} H=-36.72 \mathrm{~kJ} / \mathrm{mol}^{43}$

$x=0.3, \delta=0.11, T=298 \mathrm{~K}, \Delta^{\circ} H=-17.9 \mathrm{~kJ} / \mathrm{mol}$ this work, calc.

$\Delta{ }^{\circ} H=-20.48 \mathrm{~kJ} / \mathrm{mol}^{43}$ 
$1573 \mathrm{~K}$ and oxygen partial pressures below $10^{-5} \mathrm{~Pa}$. The best agreement is obtained with the newer experimental data from Hilpert et al. ${ }^{45}$

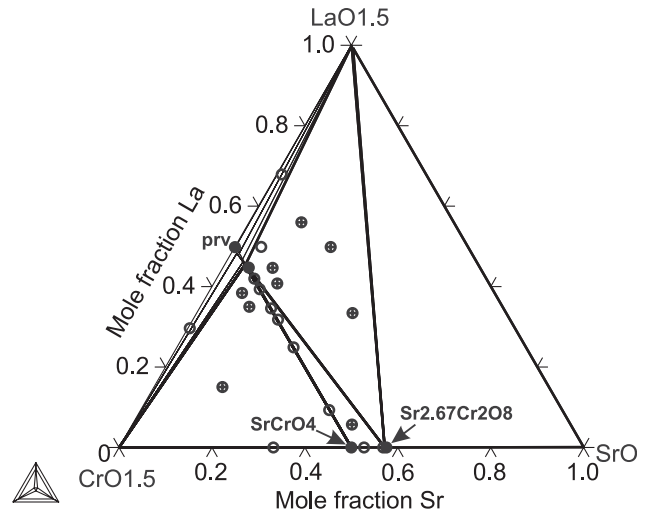

FIG. 4. $\mathrm{LaO}_{1.5}-\mathrm{SrO}-\mathrm{CrO}_{1.5}$ system calculated at $1223 \mathrm{~K}$ in air atmosphere (solid lines) with experimental data ${ }^{38}$ included (symbols). prv $=\mathrm{La}_{1-x} \mathrm{Sr}_{x} \mathrm{CrO}_{3-\delta}$. Calculated phase equilibria are the same as in Ref. 38. Filled circles, blank circles, and circles with crosses denote single-phase, two-phase, and three-phase equilibria. Thin lines (conodes) connect phase compositions of two coexisting equilibrium phases.

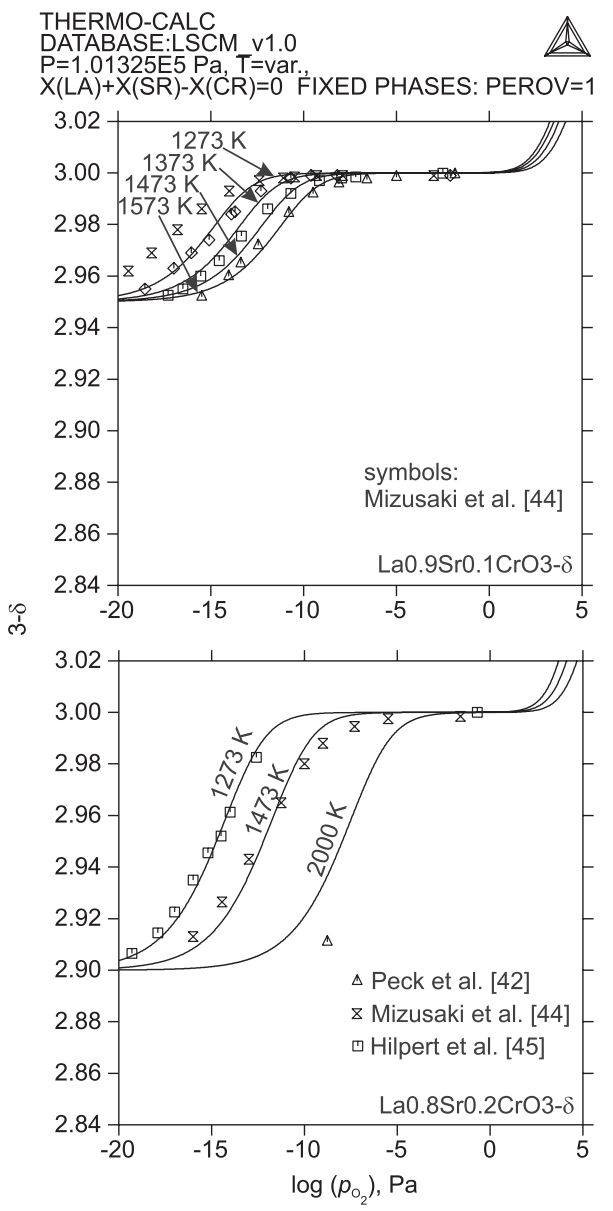

\section{2. $\mathrm{LaMn}_{1-x} \mathrm{Cr}_{x} \mathrm{O}_{3-\delta}$}

All end-member compounds of $\mathrm{LaMn}_{1-x} \mathrm{Cr}_{x} \mathrm{O}_{3-\delta}$ have been defined in the assessed subsystems. The interaction parameter ${ }^{0} L\left(\mathrm{La}^{3+}: \mathrm{Cr}^{3+}, \mathrm{Mn}^{3+}: \mathrm{O}^{2-}\right)$ accounting for interaction energies between $\mathrm{Cr}$ and $\mathrm{Mn}$ cations is fitted to experimental nonstoichiometries ${ }^{47} ;{ }^{0} L_{\left(\mathrm{La}^{3+}\right.}: \mathrm{Cr}^{3+}$, $\left.\mathrm{Mn}^{3+}: \mathrm{O}^{2-}\right)=+8500 \mathrm{~J}$. The calculated isothermal section of the $\mathrm{La}-\mathrm{Mn}-\mathrm{Cr}-\mathrm{O}$ oxide system at $1273 \mathrm{~K}$ in air is presented in Fig. 6.

Currently, the calculated $\mathrm{La}-\mathrm{Cr}-\mathrm{Mn}-\mathrm{O}$ oxide phase diagram is supported only by a single experimental information on complete solid solution of the perovskite phase from $\mathrm{LaCrO}_{3}$ to $\mathrm{LaMnO}_{3}$. Thus, there will be considerable potential of evaluation and refinement of model parameters, when further experimental work on phase equilibria at different temperatures is performed. In the context of SOFC research, a detailed investigation of the stability limits of the perovskite stability will be beneficial. As shown in Fig. 7, the calculated nonstoichiometries of $\mathrm{La}_{1-x} \mathrm{Sr}_{x} \mathrm{CrO}_{3-\delta}$ are in good agreement with the experimental values at higher temperatures, the difference being smaller at lower oxygen partial pressures.

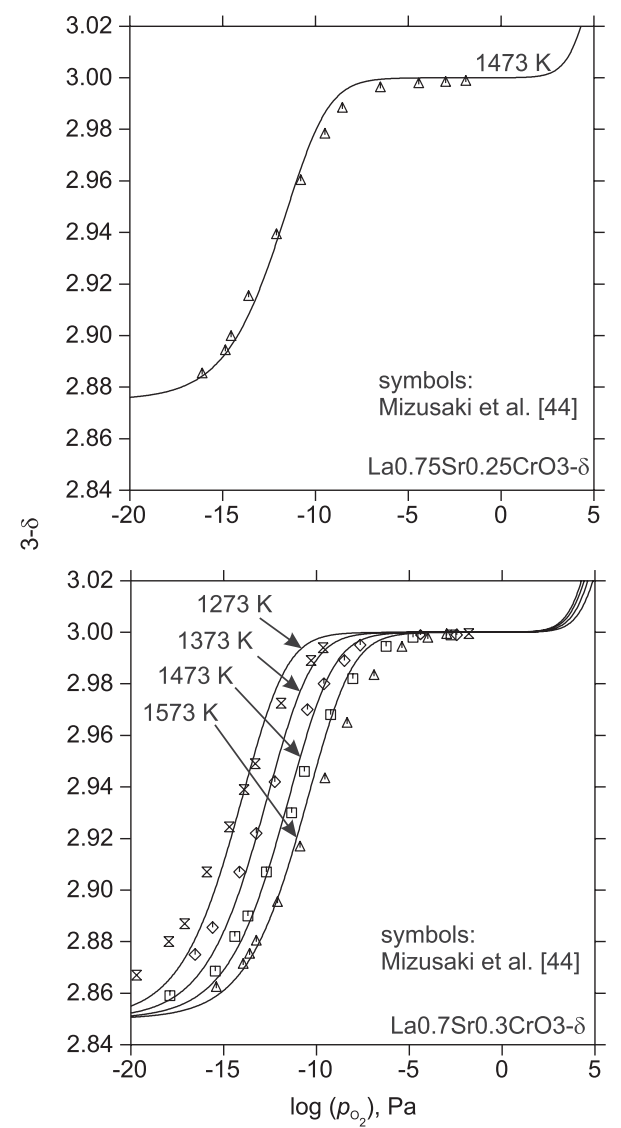

FIG. 5. Calculated (lines) and experimental (symbols) ${ }^{44,45}$ nonstoichiometries of $\mathrm{La}_{1-x} \mathrm{Sr}_{x} \mathrm{CrO}_{3-\delta}$ at different temperatures for $x=0.1,0.2,0.25$, and 0.3 as a function of oxygen partial pressure. 


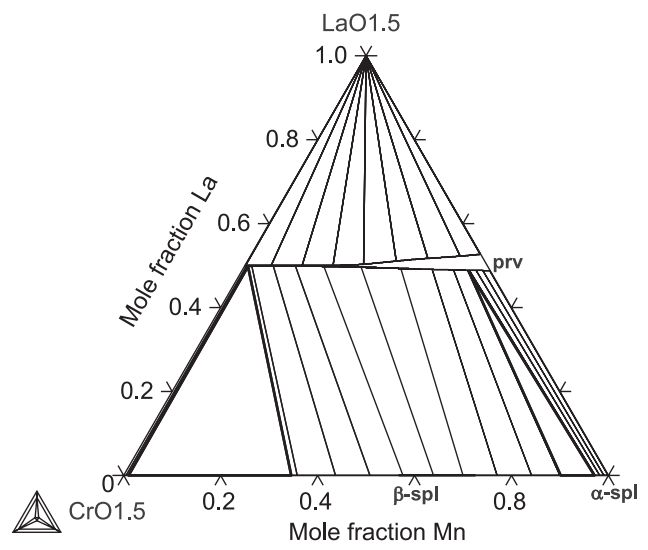

FIG. 6. $\mathrm{LaO}_{1.5}-\mathrm{MnO}_{x}-\mathrm{CrO}_{1.5}$ system calculated at $1273 \mathrm{~K}$ in air atmosphere. $\alpha$-spl $=$ tetragonally distorted $\mathrm{Cr}-\mathrm{Mn}$-spinel, $\beta$-spl $=$ cubic $\mathrm{Cr}-\mathrm{Mn}-$ spinel, prv $=\mathrm{LaMn}_{1-x} \mathrm{Cr}_{x} \mathrm{O}_{3-\delta}$. Thin lines (conodes) connect phase compositions of two coexisting equilibrium phases.

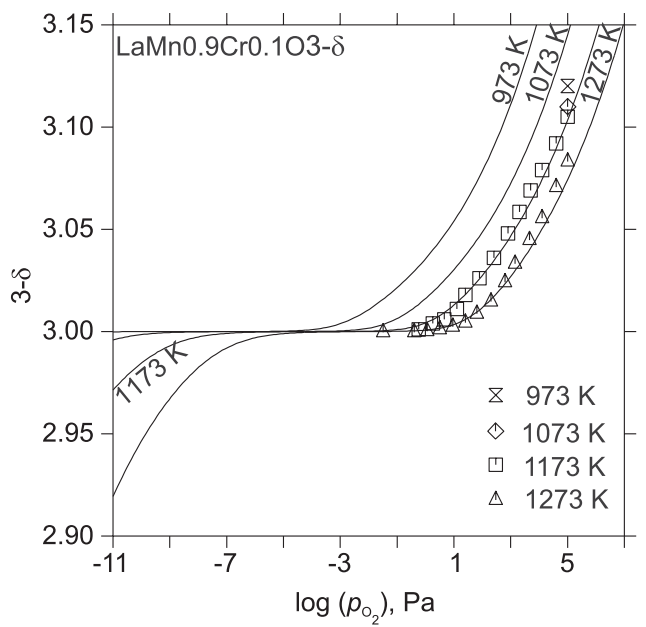

FIG. 7. Calculated (lines) and experimental (symbols) ${ }^{47}$ nonstoichiometries of $\mathrm{LaMn}_{0.9} \mathrm{Cr}_{0.1} \mathrm{O}_{3-\delta}$ at different temperatures as a function of oxygen partial pressure.

However, it was not possible to better reproduce the nonstoichiometries at 1073 and $973 \mathrm{~K}$ by any combinations of interaction parameters that can influence the oxygen nonstoichiometry. The gross difference between the measured thermal evolution of oxygen nonstoichiometry from 1173 to $1073 \mathrm{~K}$ in comparison to the change of $\delta$ from 1273 to $1173 \mathrm{~K}$ is not intuitive. Thus, we believe that the experimental increase of $\delta$ from 1173 to $1073 \mathrm{~K}$ might be too small, possibly caused by equilibration difficulties due to slow diffusion at these lower temperatures.

\section{Structural and magnetic transitions of perovskite}

Magnetic and structural transitions
$\mathrm{La}_{1-x} \mathrm{Sr}_{x} \mathrm{CrO}_{3-\delta},{ }_{5-62}$ of
$\mathrm{LaMn}_{1-x} \mathrm{Sr}_{x} \mathrm{Mn}_{1-y} \mathrm{Cr}_{y} \mathrm{O}_{3-\delta} \mathrm{Cr}_{x} \mathrm{O}_{3-\delta}, 63$ were reported. Transitions
of $\mathrm{LaMn}_{1-x} \mathrm{Cr}_{x} \mathrm{O}_{3-\delta}$ are complex as they depend on

temperature, composition, and oxygen partial pressure. Consistency among transition data for $\mathrm{La}_{1-x} \mathrm{Sr}_{x} \mathrm{CrO}_{3-\delta}$ and $\mathrm{LaMn}_{1-x} \mathrm{Cr}_{x} \mathrm{O}_{3-\delta}$ prevails, whereas diversities exist regarding the transitions in $\mathrm{La}_{1-x} \mathrm{Sr}_{x} \mathrm{Mn}_{1-y} \mathrm{Cr}_{y} \mathrm{O}_{3-\delta}$. Thus, in terms of the applicability of the new database for SOFC, the authors omit structural transitions in the modeling. Even though magnetic transitions have been reproduced by an ordering model ${ }^{69,70}$ in the case of $\mathrm{LaCrO}_{3},{ }^{20}$ we did not obtain satisfying results in higher-order perovskites, most likely due to more complex interactions that cannot be sufficiently described by the model. Since the magnetic transitions are low temperature features, their modeling was omitted without consequences for the applicability of the database for SOFC.

\section{SUMMARY}

The thermodynamic $\mathrm{La}-\mathrm{Sr}-\mathrm{Mn}-\mathrm{Cr}-\mathrm{O}$ oxide database has been obtained by combining thermodynamic assessments of oxide subsystems. We propose the model $\left(\mathrm{La}^{3+}\right.$, $\left.\mathrm{Sr}^{2+}, \mathrm{Va}\right)\left(\mathrm{Mn}^{2+}, \mathrm{Mn}^{3+}, \mathrm{Mn}^{4+}, \mathrm{Cr}^{3+}, \mathrm{Cr}^{4+}, \mathrm{Va}\right)\left(\mathrm{O}^{2-}, \mathrm{Va}\right)_{3}$ for the complex perovskite phase. Optimized by experiments in pseudoternary and pseudoquaternary oxide subsystems, this model allows the quantitative calculation of defects as a function of composition, temperature, and oxygen partial pressure. Refinement of the presented Gibbs energy functions can be obtained when further experimental data are provided, in particular, the experimental validation of the stability limits of single-phase $\mathrm{La}-\mathrm{Cr}-\mathrm{Mn}$ perovskite. Since the modeling is sufficiently supported by thermodynamic and qualitative phase diagram data at working temperatures of conventional SOFC, the new database is considered to be of practical value for computations of phase equilibria and defect chemistry in traditional LSM SOFC cathode poisoned by chromium. Thus, in terms of the endurability of traditional SOFC, one can learn about the evolution of phases in Cr-contaminated LSM in an oxygen partial pressure gradient at SOFC working temperatures. Care was taken that the modeling of the perovskite phase is consistent with other assessments of perovskite-containing systems with relevance for SOFC, and the database can thus, to better understand the thermodynamics of noble symmetric SOFC configurations, be further extended without restatement of model descriptions.

\section{REFERENCES}

1. J.C. Ruiz-Morales, D. Marrero-López, J. Canales-Vázquez, and J.T. S. Irvine: Symmetric and reversible solid oxide fuel cells. RSC Adv. 1, 1403-1414 (2011).

2. D.M. Bastidas, S. Tao, and J.T.S. Irvine: A symmetrical solid oxide fuel cell demonstrating redox stable perovskite electrodes. J. Mater. Chem. 16, 1603-1605 (2006).

3. J.C. Ruiz-Morales, J. Canales-Vázquez, J Peña-Martínez, D. Marrero-López, and P. Núñez: On the simultaneous use of 
$\mathrm{La}_{0.75} \mathrm{Sr}_{0.25} \mathrm{Cr}_{0.5} \mathrm{Mn}_{0.5} \mathrm{O}_{3-\delta}$ as both anode and cathode material with improved microstructure in solid oxide fuel cells. Electrochim. Acta 52, 278-284 (2006).

4. S.P.S. Badwal, R. Deller, K. Foger, Y. Ramprakash, and J.P. Zhang: Interaction between chromia forming alloy interconnects and air electrode of solid oxide fuel cells. Solid State Ionics 99, 297-310 (1997).

5. S.P. Jiang, J.P. Zhang, and K. Foger: Deposition of chromium species at $\mathrm{Sr}$-doped $\mathrm{LaMnO}_{3}$ electrodes in solid oxide fuel cells - III. Effect of air flow. J. Electrochem. Soc. 148, C447-C455 (2001).

6. N. Saunders and A.P. Miodownik: Calphad calculation of phase diagrams. In Pergamon Materials Series; Vol. 1. (Elsevier Science Ltd., Oxford, UK, 1998).

7. H.L. Lukas, S.G. Fries, and B. Sundman: Computational Thermodynamics. The CALPHAD Method (Cambridge University Press, Cambridge, UK, 2007).

8. Z-K. Liu: First-principles calculations and Calphad modeling of thermodynamics. J. Phase Equilib. Diffus. 30, 517-534 (2009).

9. A.T. Dinsdale: SGTE data for pure elements. Calphad 15, 317-425 (1991).

10. J-O. Andersson, A.F. Guillermet, M. Hillert, B. Jansson, and B. Sundman: A compound-energy model of ordering in a phase with sites of different coordination numbers. Acta Metall. 34, 437 (1986).

11. M. Hillert, B. Jansson, and B. Sundman: Application of the compound-energy model to oxide systems. Z. Metallkd. 79, 81-87 (1988).

12. M. Hillert: The compound energy formalism. J. Alloys Compd. 320, 161-176 (2001).

13. O. Redlich and A.T. Kister: Algebraic representations of thermodynamic properties and the classification of solutions. Ind. Eng. Chem. 40, 345-348 (1948).

14. A.N. Grundy, E. Povoden, T. Ivas, and L.J. Gauckler: Calculation of defect chemistry using the CALPHAD approach. Calphad 30, 33-41 (2006).

15. B. Sundman, B. Jansson, and J-O. Andersson: The thermo-calc databank system. Calphad 9, 153-190 (1985).

16. E.A. Filonova, A.N. Demina, and A.N. Petrov: Phase equilibria in the system $\mathrm{LaMnO}_{3}-\mathrm{SrMnO}_{3}-\mathrm{SrCrO}_{4}-\mathrm{LacrO}_{3}$. Russ. J. Inorg. Chem. 52, 771-774 (2007).

17. A.N. Grundy, B. Hallstedt, and L.J. Gauckler: Thermodynamic assessment of the lanthanum-oxygen system. J. Phase Equilib. 22, 105-113 (2001)

18. M. Zinkevich, S. Geupel, F. Aldinger, A. Durygin, S.K. Saxena, M. Yang, and Z-K. Liu: Phase diagram and thermodynamics of the $\mathrm{La}_{2} \mathrm{O}_{3}-\mathrm{Ga}_{2} \mathrm{O}_{3}$ system revisited. J. Phys. Chem. Solids 67, 19011907 (2006).

19. E. Povoden, A.N. Grundy, and L.J. Gauckler: Thermodynamic reassessment of the $\mathrm{Cr}-\mathrm{O}$ system in the framework of solid oxide fuel cell (SOFC) research. J. Phase Equilib. Diffus. 27, 353-362 (2006).

20. E. Povoden, M. Chen, A.N. Grundy, T. Ivas, and L.J. Gauckler: Thermodynamic assessment of the La-Cr-O system. J. Phase Equilib. Diffus. 30, 12-27 (2009).

21. E. Povoden, A.N. Grundy, L.J. Gauckler: Thermodynamic assessment of the Mn-Cr-O system for solid oxide fuel cell (SOFC) materials. Int. J. Mater. Res. 97, 569-578 (2006).

22. A.N. Grundy, B. Hallstedt, and L.J. Gauckler: Assessment of the Mn-O system. J. Phase Equilib. 24, 21-39 (2003).

23. A.N. Grundy, M. Chen, B. Hallstedt, and L.J. Gauckler: Assessment of the La-Mn-O system. J. Phase Equilib. Diffus. 26, 131-151 (2005).

24. A.N. Grundy, B. Hallstedt, and L.J. Gauckler: $\mathrm{La}_{1-x} \mathrm{Mn}_{1-y} \mathrm{O}_{3-z}$ perovskites modeled with and without antisite defects using the CALPHAD approach. Solid State Ionics 173, 17-21 (2004).

25. A.N. Grundy, B. Hallstedt, and L.J. Gauckler: Experimental phase diagram determination and thermodynamic assessment of the $\mathrm{La}_{2} \mathrm{O}_{3}$-SrO system. Acta Mater. 50, 2209-2222 (2002).
26. A.N. Grundy, B. Hallstedt, and L.J. Gauckler: Assessment of the Sr-Mn-O system. J. Phase Equilib. Diffus. 25, 311-319 (2004).

27. A.N. Grundy, B. Hallstedt, and L.J. Gauckler: Assessment of the La-Sr-Mn-O system. Calphad 28, 191-201 (2004).

28. R.D. Shannon and C.T. Prewitt: Effective ionic radii in oxides and fluorides. Acta Crystallogr., Sect. B: Struct. Sci 25, 925-946 (1969).

29. K. Hack, (Ed.): The SGTE Casebook: Thermodynamics at Work (Institute of Materials, London, 1996).

30. H. Yokokawa, N. Sakai, T. Kawada, and M. Dokiya: Chemical thermodynamic considerations in sintering of $\mathrm{LaCrO}_{3}$-based perovskites. J. Electrochem. Soc. 138, 1018-1027 (1991).

31. K.T. Jacob and K.P. Abraham: Phase relations in the system Sr-Cr-O and thermodynamic properties of $\mathrm{SrCrO}_{4}$ and $\mathrm{Sr}_{3} \mathrm{Cr}_{2} \mathrm{O}_{8}$. J. Phase Equilib. 21, 46-53 (2000).

32. T. Maruyama, T. Inoue, and T. Akashi: Standard Gibbs energies of formation of $\mathrm{SrCrO}_{4}$ and $\mathrm{Sr}_{3} \mathrm{Cr}_{2} \mathrm{O}_{8}$. Mater. Trans., JIM 39, 1158-1161 (1998)

33. A.M. Azad, R. Sudha, and O.M. Sreedharan: The standard Gibbs energies of formation of $\mathrm{ACrO}_{4}(\mathrm{~A}=\mathrm{Ca}, \mathrm{Sr}$ or $\mathrm{Ba})$ from emfmeasurements. Thermochim. Acta 194, 129-136 (1992).

34. R. Akila and K.T. Jacob: The mobility of oxygen in $\mathrm{CaF}_{2}$. J. Appl. Electrochem. 20, 294-300 (1990).

35. Y.K. Kisil, N.G. Sharova, and B.V. Slobodin: Phase formation in the system $\mathrm{SrO}-\mathrm{CrO}_{3}-\mathrm{Cr}_{2} \mathrm{O}_{3}$. Inorg. Mater. 25, 1490-1491 (1989).

36. E. Castillo-Martínez and M.A. Alario-Franco: Revisiting the $\mathrm{Sr}-\mathrm{Cr}$ (IV)-O system at high pressure and temperature with special reference to $\mathrm{Sr}_{3} \mathrm{Cr}_{2} \mathrm{O}_{7}$. Solid State Sci. 9, 564-573 (2007).

37. T. Negas and R.S. Roth: System SrO-Chromium oxide in air and oxygen. J. Res. Nat. Bur. Stand. A Phys. Chem. 73, 431-442 (1969).

38. D.H. Peck, M. Miller, and K. Hilpert: Phase diagram studies in the $\mathrm{SrO}-\mathrm{Cr}_{2} \mathrm{O}_{3}-\mathrm{La}_{2} \mathrm{O}_{3}$ system in air and under low oxygen partial pressure. Solid State Ionics 123, 59-65 (1999).

39. K. Hartl and R. Braungart: Strontiumchromate(V, VI), $\mathrm{Sr}_{2.67} \mathrm{Va}_{0.33}\left(\mathrm{CrO}_{4}\right)_{1.33}\left(\mathrm{CrO}_{4}\right)_{0.67}$, a high-temperature compound with defect-bariumphosphate-structure. Z. Naturforsch., B: Chem. Sci. 33, 952-953 (1978) [in German].

40. S. Miyoshi, S. Onuma, A. Kaimai, H. Matsumoto, K. Yashiro, T. Kawada, J. Mizusaki, and H. Yokokawa: Chemical stability of $\mathrm{La}_{1-x} \mathrm{Sr}_{x} \mathrm{CrO}_{3}$ in oxidizing atmospheres. J. Solid State Chem. 177, 4112-4118 (2004).

41. S.N. Ruddlesden and P. Popper: The compound $\mathrm{Sr}_{3} \mathrm{Ti}_{2} \mathrm{O}_{7}$ and its structure. Acta Crystallogr. 11, 54-55 (1958).

42. D-H. Peck, M. Miller, and K. Hilpert: Vaporization and thermodynamics of $\mathrm{La}_{1-x} \mathrm{Sr}_{x} \mathrm{CrO}_{3-\delta}$ investigated by Knudsen effusion mass spectrometry. Solid State Ionics 143, 401-412 (2001).

43. J. Cheng and A. Navrotsky: Energetics of $\mathrm{La}_{1-x} \mathrm{~A}_{x} \mathrm{CrO}_{3-\delta}$ perovskites (A = Ca or Sr). J. Solid State Chem. 178, 234-244 (2005).

44. J. Mizusaki, S. Yamauchi, K. Fueki, and A. Ishikawa: Nonstoichiometry of the perovskite-type oxide $\mathrm{La}_{1-x} \mathrm{Sr}_{x} \mathrm{CrO}_{3-\delta}$. Solid State Ionics 12, 119-124 (1984).

45. K. Hilpert, R.W. Steinbrech, F. Boroomand, E. Wessel, F. Meschke, A. Zuev, O. Teller, H. Nickel, and L. Singheiser: Defect formation and mechanical stability of perovskites based on $\mathrm{LaCrO}_{3}$ for solid oxide fuel cells (SOFC). J. Eur. Cer. Soc. 23, 3009-3020 (2003).

46. H. Yokokawa, T. Horita, N. Sakai, K. Yamaji, M.E. Brito, Y-P. Xiong, and H. Kishimoto: Thermodynamic considerations on Cr poisoning in SOFC cathodes. Solid State Ionics 177, 3193 3198 (2006).

47. L. Morales and A. Caneiro: Evolution of crystal structure with the oxygen content in the $\mathrm{LaMn}_{0.9} \mathrm{Cr}_{0.1} \mathrm{O}_{3+\delta}(3.00 \leq 3+\delta \leq 3.12)$ compound. J. Solid State Chem. 170, 404-410 (2003).

48. S.M. Plint, P.A. Connor, S. Tao, and J.T.S. Irvine: Electronic transport in the novel SOFC anode material $\mathrm{La}_{1-x} \mathrm{Sr}_{x} \mathrm{Cr}_{0.5} \mathrm{Mn}_{0.5} \mathrm{O}_{3 \pm \delta}$. Solid State Ionics 177, 2005-2008 (2006). 
49. T. Komatsu, R. Chiba, H. Arai, and K. Sato: Chemical compatibility and electrochemical property of intermediate-temperature SOFC cathodes under $\mathrm{Cr}$ poisoning condition. J. Power Sources 176, 132-137 (2008).

50. D. Risold, B. Hallstedt, and L.J. Gauckler: The strontium-oxygen system. Calphad 20, 353-361 (1996).

51. M. Hillert, B. Jansson, B. Sundman, and J. Ågren: A two-sublattice model of molten solutions with different tendency of ionization. Metall. Trans. A 16, 261-266 (1985).

52. B. Sundman: Modification of the two-sublattice model for liquids. Calphad 15, 109-119 (1991).

53. W. Hastie and D.W. Bonnell: A predicitive phase-equilibrium model for multicomponent oxide mixtures. 2. Oxides of Na-K-Ca-Mg-Al-Si. High Temp. Sci. 19, 275-306 (1985).

54. D.W. Bonnell and J.W. Hastie: A predictive thermodynamic model for complex high-temperature solution phases II. High Temp. Sci. 26, 313-334 (1989).

55. A.D. Pelton and P. Chartrand: The modified quasi-chemical model: Part II. Multicomponent solutions. Metall. Mater. Trans. A 32, 1355-1360 (2001).

56. C.P. Khattak and D.E. Cox: Structural studies of (La, $\mathrm{Sr}) \mathrm{CrO}_{3}$ system. Mater. Res. Bull. 12, 463-472 (1977).

57. K. Tezuka, Y. Hinatsu, A. Nakamura, T. Inami, Y. Shimojo, and Y. Morii: Magnetic and neutron diffraction study on perovskites $\mathrm{La}_{1-x} \mathrm{Sr}_{x} \mathrm{CrO}_{3}$. J. Solid State Chem. 141, 404-410 (1998).

58. K. Tezuka, Y. Hinatsu, K. Oikawa, Y. Shimojo, and Y. Morii: Studies on magnetic properties of $\mathrm{La}_{0.95} \mathrm{Sr}_{0.05} \mathrm{CrO}_{3}$ and $\mathrm{La}_{0.85} \mathrm{Sr}_{0.15}$ $\mathrm{CrO}_{3}$ by means of powder neutron diffraction. J. Phys.: Condens. Matter 12, 4151-4160 (2000).

59. F. Nakamura, Y. Matsunaga, N. Oba, K. Arai, H. Matsubara, H. Takahashi, and T. Hashimoto: Analysis of magnetic and structural phase transition behaviors of $\mathrm{La}_{1-x} \mathrm{Sr}_{x} \mathrm{CrO}_{3}$ for preparation of phase diagram. Thermochim. Acta 435, 222-229 (2005).

60. K.R. Chakraborty, S.M. Yusuf, P.S.R. Krishna, M. Ramanadham, A.K. Tyagi, and V. Pomjakushin: Structural study of $\mathrm{La}_{0.75} \mathrm{Sr}_{0.25} \mathrm{CrO}_{3}$ at high temperatures. J. Phys.: Condens. Matter 18, 8661-8672 (2006).

61. Y. Matsunaga, F. Nakamura, H. Takahashi, and T. Hashimoto: Analysis of relationship between magnetic property and crystal structure of $\mathrm{La}_{1-x} \mathrm{Sr}_{x} \mathrm{CrO}_{3}(x=0.13,0.15)$. Solid State Commun. 145, 502-506 (2008).

62. Y. Matsunaga, H. Kawaji, T. Atake, H. Takahashi, and T. Hashimoto: Magnetization and resistivity in chromium doped manganites. Thermochim. Acta 474, 57-61 (2008).

63. O. Cabeza, M. Long, M.A. Bari, C.M. Muirhead, M.G. Francesconi, and C. Greaves: Magnetization resistivity chromium doped manganites. J. Phys.: Condens. Matter 11, 2569-2578 (1999).

64. Z. El-Fadli, M.R. Metni, F. Sapiña, E. Martinez, J.V Folgado, D. Beltrán, A. Beltrán: Structural effects of Co and Cr substitution in $\mathrm{LaMnO}_{3+\delta}$. J. Mater. Chem. 10, 437-443 (2000).

65. M. Tseggai, P. Nordblad, R. Tellgren, H. Rundlöf, G. Andrè, and F. Bourèe: Synthesis, nuclear structure, and magnetic properties of $\mathrm{LaCr}_{1-y} \mathrm{Mn}_{y} \mathrm{O}_{3}(y=0,0.1,0.2$, and 0.3). J. Alloys Compd. 457, 532-540 (2008).

66. S.A. Howard, J-K. Yau, and H.U. Anderson: X-ray-powder diffraction structural phase-transition study of $\mathrm{La}\left(\mathrm{Cr}_{1-x} \mathrm{Mn}_{x}\right) \mathrm{O}_{3}$ ( $x=0$ to 0.25 ) using the Rietveld method of analysis. J. Am. Ceram Soc. 75, 1685-1687 (1992).

67. M. Hrovat, S. Bernik, J. Holc, D. Kuscer, and D. Kolar: Preliminary data on solid solubility between $\mathrm{LaCrO}_{3}$ and $\mathrm{LaFeO}_{3}$ or $\mathrm{LaMnO}_{3}$. J. Mater. Sci. Lett. 16, 143-146 (1997).

68. N. Kallel, J. Dhahri, S. Zemni, E. Dhahri, M. Oumezzine, M. Ghedira, and $\mathrm{H}$. Vincent: Effect of $\mathrm{Cr}$ doping in $\mathrm{La}_{0.7} \mathrm{Sr}_{0.3} \mathrm{Mn}_{1-x} \mathrm{Cr}_{x} \mathrm{O}_{3}$ with $0 \leq x \leq 0.5$. Phys. Status Solidi $A$ 184, 319-325 (2001).

69. G. Inden: Determination of chemical and magnetic interchange energies in bcc alloys. I. General treatment. Z. Metallkd. 66, 577-582 (1975).

70. M. Hillert and M. Jarl: A model of alloying effects in ferromagnetic metals. Calphad 2, 227-238 (1978).

\section{Supplementary Material}

Supplementary material can be viewed in this issue of the Journal of Materials Research by visiting http://journals.cambridge.org/jmr. 